\title{
Enhancing Mango Productivity through Sustainable Resource Management
}

\author{
A.N. Ganeshamurthy*, T.R. Rupa and T.N. Shivananda \\ ICAR-Indian Institute of Horticultural Research, Hessaraghatta, Bengaluru \\ *E-mail: angmurthy@ gmail.com
}

\section{INTRODUCTION}

Mango the "King of fruits" is the most important fruit crop in India and the area under mango is the largest among fruit crops (2,516 thousand ha) with a production of around 19.69 million tonnes. India ranks first in mango production in the world contributing $41 \%$ of the total world production of mango. Among Indian states, with a total output of 4.3 million MT, Uttar Pradesh stands first as mango producing state. (Fig.1).This is followed by Telangana (2.73 million MT), Karnataka (1.75 million MT) and Bihar (1.36 million MT). Particularly in India all stages of mango fruit are used starting from immature to over ripe stages. Mango has specific problem of alternate bearing leading many times to low yields or no yield.

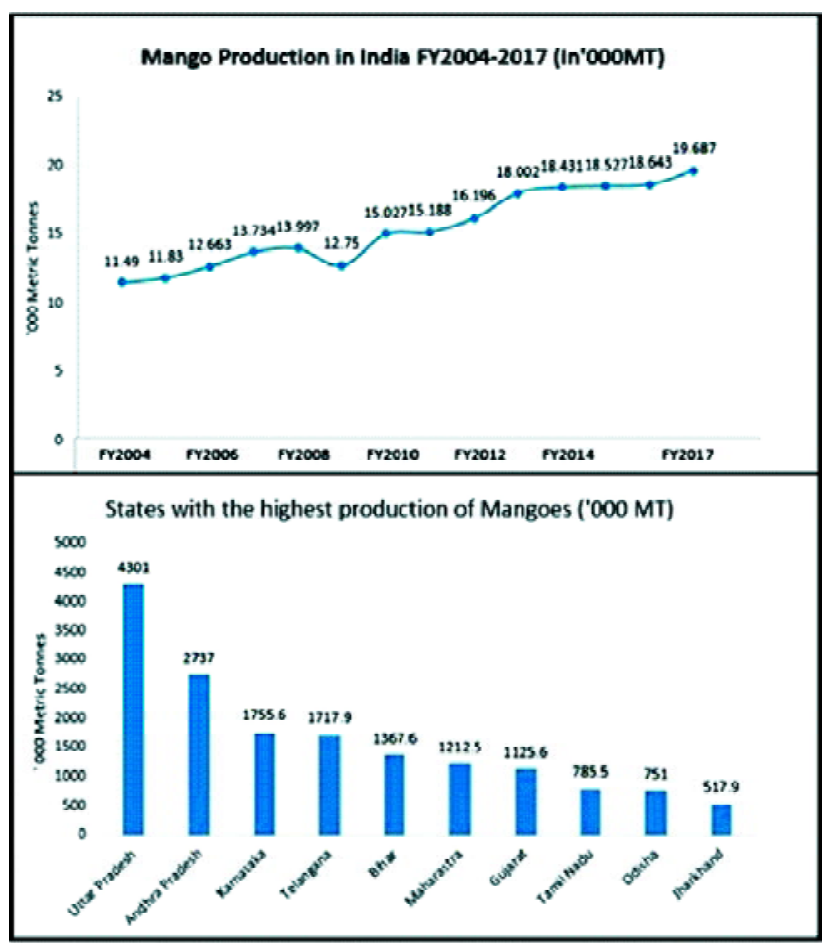

Fig 1. Trends in mango production in India

The tree is hardy in nature, can be grown in a variety of soils and requires comparatively low maintenance costs. But poor soil, nutrient and water management are the key factors for declining productivity of mango over the years. One of the main reasons for the low productivity is imbalances in nutrient application and inadequate fertilization. An appraisal on soil nutrient deficiencies and superimposing specific crop for district-wise crop based nutrient delineation maps is essential for preparing strategic guide in realizing potential yields of mango by formulating appropriate fertilization schedule. The status of soil fertility in mango growing areas under different agro-ecological regions of India and the district-wise crop based nutrient delineation maps of prime mango producing states of India along with nutrient deficiency symptoms in the plant and their management is presented here.

\section{World scenario of mango production}

Before 1960, mango was not a tradable commodity and virtually there was no international trade of fresh fruit. However, in recent years the international trade of mango fresh fruits and its processed products become well established. India and other Asian countries produce the major share of global mango of which India alone produces an average of 19.69 million tonnesa year. The cultivation has now spread to more than 100 countries. There are more than 65 countries which produce more than $1,000 \mathrm{MT}$ a year contributing to the total $40 \mathrm{MT}$ global production of mangoes (Table 1).The demand for mango fruits, particularly from temperate countries, is increasing.EU countries and the USA are the leading importers of fresh fruits. Though the main mango season is March to July, today we have an extended period of mango availability due to extended season in other countries like Venezuela, Kenya, Columbia and Brazil, (Mitra 2016). Though the mango season is expanding, the preferred varieties are grown in Asian countries with India alone having nearly 1,300 cultivars (although 20 grown commercially) followed by Thailand having about 100 varieties. 


\section{Mango crop boundary in India}

Mango is grown throughout the country on all types of soils and in all the agro ecological sub regions except in very cold or extremely dry desert areas. Based on area and production, ten states were identified as prime mango producing states of India (Fig. 2).
Similarly within these states, based on categorization with respect to area and production per unit area, one hundred eleven districts were identified as prime mango growing districts (Table 2). The boundary map of mango was prepared using district maps of respective leading mango producing states (Ganeshamurthyetal.2016a).

Table 1: Area, production and productivity in leading mango producing countries of the world (Source: FAO, 2017)

\begin{tabular}{|l|c|c|c|c|c|}
\hline Country & Area $(\mathrm{m}$ ha) & Share $(\%)$ & Production (million tonne) & Share $(\%)$ & Productivity $\left(\mathrm{t} \mathrm{ha}^{-1}\right)$ \\
\hline India & 2.52 & 46.0 & 19.69 & 41.6 & 6.92 \\
\hline China & 0.48 & 8.8 & 4.62 & 10.7 & 9.6 \\
\hline Thailand & 0.38 & 7.0 & 3.14 & 7.3 & 8.27 \\
\hline Indonesia & 0.2 & 3.7 & 2.06 & 4.8 & 10.5 \\
\hline Mexico & 0.2 & 3.7 & 1.9 & 4.4 & 9.56 \\
\hline Pakistan & 0.17 & 3.1 & 1.66 & 3.8 & 9.68 \\
\hline Brazil & 0.07 & 1.3 & 1.16 & 2.7 & 16.53 \\
\hline Bangladesh & 0.12 & 2.2 & 0.95 & 2.2 & 7.66 \\
\hline Nigeria & 0.13 & 2.4 & 0.85 & 2.0 & 6.54 \\
\hline Egypt & 0.09 & 1.7 & 0.83 & 1.9 & 9.09 \\
\hline Others & 1.1 & 20.2 & 8.12 & 18.8 & 7.41 \\
\hline World & 5.44 & - & 43.3 & - & 7.96 \\
\hline
\end{tabular}

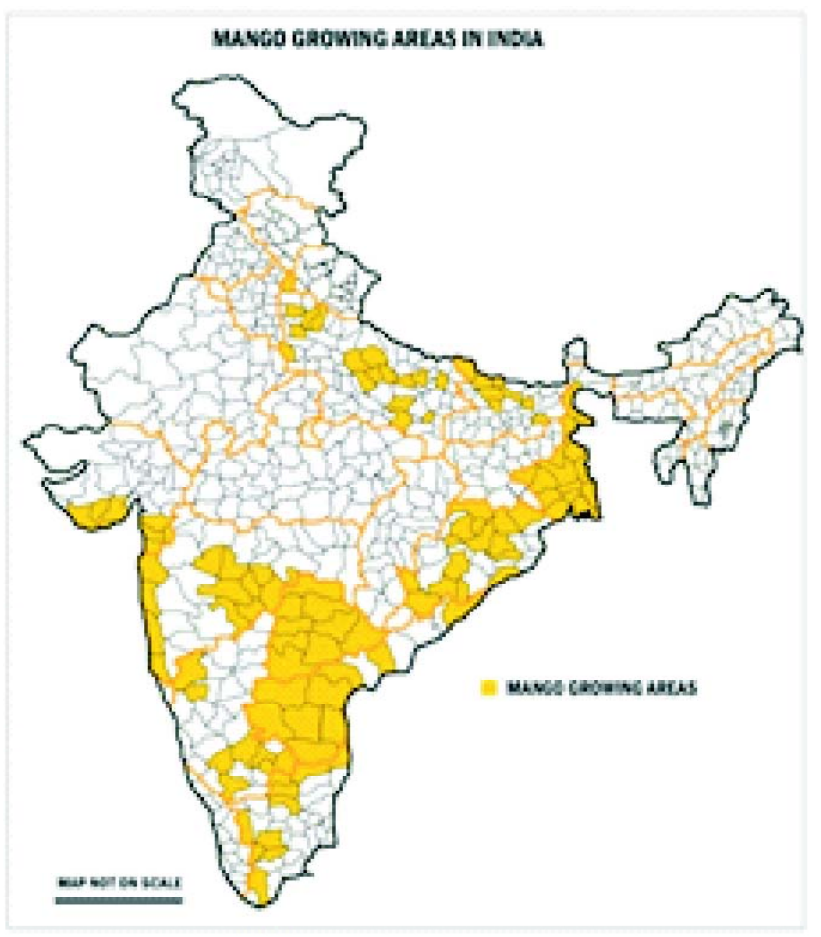

Fig. 2. Major mango growing areas in India

\section{Problems in mango production}

\section{Very low average productivity}

The area and production of mango has been continuously increasing over the years (Table 3). Over the years though the overall productivity is increasing, the productivity levels are very low compared to other countries. The area under mango cultivation was just 1077.6 thousand ha during 1991-92. It has increased to 2262.8 thousand ha in 2016-17. There has been drastic fluctuation in production of mango. Between 1991-92 and 2007-08, the production increased from 8715.6 thousand MT to 13997 thousand MT. But in 2008-09 the production declined to 12750 thousand MT. From 2009 onwards there has been a continuous increase in the production (from 15026.7 thousand MT in 2009-10 to 19686.9 thousand MT in 2016-17). Between 1991-92 to 2016-17 the area increased by $210 \%$. Simultaneously the production increased by $226 \%$. The decrease in productivity during this period is just because the trees were young and yielded less which was not considered while calculating the 
Enhancing mango productivity through sustainable resource management

Table 2. Major mango growing states and districts of India

\begin{tabular}{|l|l|l|l|}
\hline S.No. & State & Districts & Area (000' ha) \\
\hline 1 & Uttar Pradesh & $\begin{array}{l}\text { Allahabad, Barabanki, Basti, Bulandshahar, Faizabad, } \\
\text { Gorakhpur, Hardoi, J.P. Nagar, Lucknow, Mathura, Meerut, } \\
\text { Moradabad, Pratapgarh, Saharanpur, Sitapur, Varanasi, Unnao }\end{array}$ & 262.16 \\
\hline 2 & $\begin{array}{l}\text { Andhra Pradesh } \\
\text { (United) }\end{array}$ & $\begin{array}{l}\text { Anantapur, Chittoor, Guntur, Kadapa, Kurnool, Nellore, } \\
\text { Prakasam, Srikakulam, West Godavari }\end{array}$ & 304.11 \\
\hline 3 & Karnataka & Bengaluru, Belgaum, Dharwad, Hassan, Kolar, Mysore, Tumkur & 180.53 \\
\hline 4 & Telangana & $\begin{array}{l}\text { Adilabad, Khammam, Mahabubnagar, Medak, Nalgonda, } \\
\text { Nizamabad, Rangareddy, Karimnagar, Warangal }\end{array}$ & 190.88 \\
\hline 5 & Bihar & $\begin{array}{l}\text { Bhagalpur, East Champaran, Darbhanga, Muzaffarpur, Saharsa, } \\
\text { Sheohar, Sitamarhi,Vaishali, West Champaran }\end{array}$ & 149.00 \\
\hline 6 & Maharashtra & $\begin{array}{l}\text { Aurangabad, Beed, Hingoli, Jalna, Latur, Mumbai, Nanded, } \\
\text { Osmanabad, Parbhani, Raigad, Ratnagiri, Sindhudurg, Thane }\end{array}$ & 485.00 \\
\hline 7 & Gujarat & Amreli, Bhavnagar, Junagadh, Navsari, Surat, The Dangs Valsad & 142.69 \\
\hline 8 & Tamil Nadu & $\begin{array}{l}\text { Coimbatore, Dharmapuri, Dindigul, Krishnagiri, Madurai, } \\
\text { Salem, Theni, Tiruvallur, Tirunelveli, Vellore }\end{array}$ & 161.58 \\
\hline 9 & Odisha & $\begin{array}{l}\text { Angul, Cuttack,Debagarh, Dhenkanal, GajapatiKandhamal, } \\
\text { Kendujhar, Koraput, Mayurbhanj, Nabaranpur, Puri, Rayagade, } \\
\text { Sundergarh, Sambalpur, Subarnapur }\end{array}$ & 197.52 \\
\hline 10 & West Bengal & $\begin{array}{l}\text { Bankura, Bardhaman, Birbhum, DakshinDinajpore Hooghly, } \\
\text { Howrah, Malda, Midnapore (West \& East), Murshidabad, } \\
\text { Nadia,24 Parganas (North \& South), Purulia, Uttar Dinajpore }\end{array}$ & 93.50 \\
\hline & All India & & $\mathbf{2 5 1 5 . 9 7}$ \\
\hline
\end{tabular}

productivity. However, except that it declined to 5.5 MT/ha in 2008-09 the productivity reached up to 8.7 MT/ha in 2016-17. There was overall increase of 7.4 $\%$ in productivity of mango from 1991-92 to 2016-17. However, the productivity of other countries are much above India (Brazil, 15.83 t/ha, Pakisthan 10.62t/ha, Indonasia 9.78t/ha, China 9.35t/ha, Mexico 9.33t/ha), (NHB 2017)

\section{Causes of poor mango productivity}

As discussed above, the productivity of mango both at domestic level and as compared to international level is very low. There are several reasons for this low productivity. A schematic presentation of the causes of low productivity is shown in Fig. 3. The causes may be either soil related or tree/orchard management related or climatic extremities or a combination of all these factors.

\section{Tree/orchard management related causes of low productivity}

The mango yields fluctuate over the years because of its alternate/irregular bearing habit. Hence

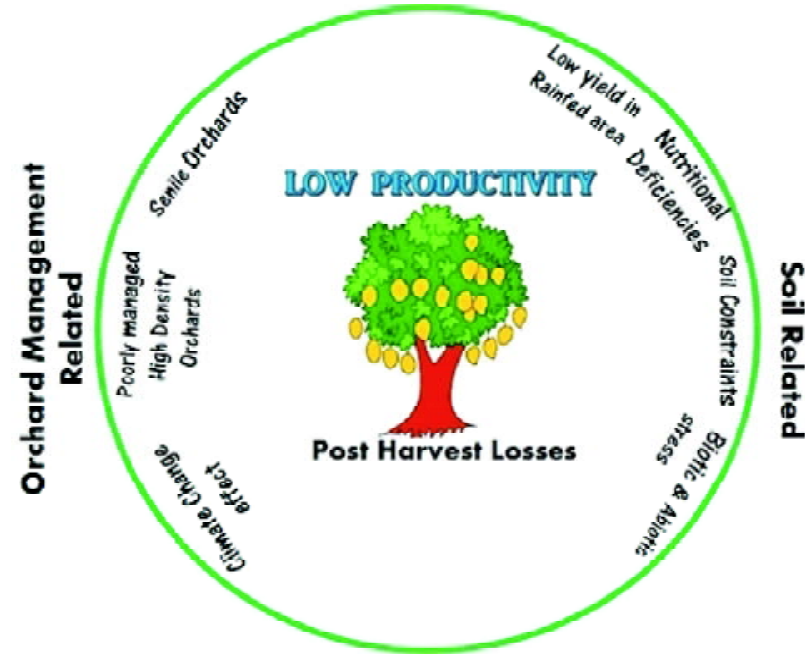

Fig. 3. Causes of low productivity of mango

mango productivity cannot be decided on single year data and should have an average of at least five years. Further, generally the mango fruit yields are generally low compared with other tropical and subtropical fruit species. The yielding capacity of a tree is dependent on variety, tree age, tree size, seasonal conditions, and previous cropping history. Typically, yields are often 
Table 3. Area, production and productivity of mango in India

\begin{tabular}{|c|c|c|c|}
\hline Year & $\begin{array}{c}\text { Area } \\
\text { (in '000 ha) }\end{array}$ & $\begin{array}{c}\text { Production } \\
\text { (in '000 MT) }\end{array}$ & $\begin{array}{c}\text { Productivity } \\
\text { (in MT/ha) }\end{array}$ \\
\hline $1991-92$ & 1078 & 8716 & 8.1 \\
\hline $2001-02$ & 1576 & 10020 & 6.4 \\
\hline $2002-03$ & 1623 & 12733 & 7.8 \\
\hline $2003-04$ & 1907 & 11490 & 6.0 \\
\hline $2004-05$ & 1970 & 11830 & 6.0 \\
\hline $2005-06$ & 2081 & 12663 & 6.1 \\
\hline $2006-07$ & 2154 & 13734 & 6.4 \\
\hline $2007-08$ & 2201 & 13997 & 6.4 \\
\hline $2008-09$ & 2309 & 12750 & 5.5 \\
\hline $2009-10$ & 2312 & 15027 & 6.5 \\
\hline $2010-11$ & 2297 & 15188 & 6.6 \\
\hline $2011-12$ & 2378 & 16196 & 6.8 \\
\hline $2012-13$ & 2500 & 18002 & 7.2 \\
\hline $2013-14$ & 2516 & 18431 & 7.3 \\
\hline $2014-15$ & 2163 & 18527 & 8.6 \\
\hline $2015-16$ & 2209 & 18643 & 8.4 \\
\hline $2016-17$ & 2263 & 19687 & 8.7 \\
\hline
\end{tabular}

(Source: Horticultural Statistics at a Glance, NHB 2018. Horticulture Statistics Division, Department of Agriculture, Cooperation \& Farmers Welfare, Ministry of Agriculture \& Farmers Welfare, Government of India.)

less than $5 \mathrm{mt} / \mathrm{ha}$ but can reach upto $20-30 \mathrm{mt} /$ ha in well managed orchards. Single trees can produce between 200 and $300 \mathrm{~kg}$ of fruit in heavy cropping years and as low as $5 \mathrm{~kg}$ in bad years. Non orchard isolated trees unusually record very high yields. For example a tree of bernishan has yielded 4.6 tonnes in a single tree in Chittoor, an Alphonso tree has yielded 3.2 tonnes in Chikkanayakanahalli in Tumkur district of Karnataka, anotheralphonso tree in Krishnagiri has yielded 2.6 tonnes. These are old trees and have unlimited exposure to light and sufficiently fed with manures. A summary of the major constraints affecting mango production in different states is given in Table 4.

i) Senility of mango trees : Decline in productivity due to old age of trees is called senility. One of the reasons for the low productivity is a large number of old mango orchards in the age group of 30 years and above, have either gone unproductive or showing marked decline in productivity. This is attributed to overcrowded and intermingled branches and meager foliage, allowing poor light penetration to growing shoots within the canopy. Only less than 30 per cent of the leaves are exposed to bright sunshine while the older leaves are hidden in shade and become photosynthetically inactive and become a burden on the tree draining the carbohydrate resources (Fig. 4). This renders

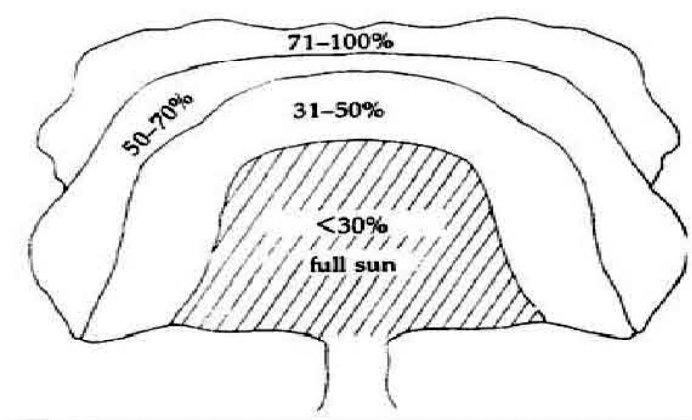

Fig. 4. A schematic view of light penetration in senile mango tree. 
Enhancing mango productivity through sustainable resource management

Table 4. Major constraints affecting mango production in different states

\begin{tabular}{|l|l|l|l|}
\hline State & Productivity (t/ha) & Major growing districts & Specific problems \\
\hline Uttar Pradesh & 16.4 & $\begin{array}{l}\text { Lucknow, Saharanpur, } \\
\text { Unnao, Bulandshahar, } \\
\text { J.P. Nagar }\end{array}$ & $\begin{array}{l}\text { Senile orchards, alternate bearing, mild } \\
\text { to moderate sodicity, nutritional } \\
\text { deficiencies, heat waves }\end{array}$ \\
\hline Andhra Pradesh & 9.0 & $\begin{array}{l}\text { Chittoor, Krishna, } \\
\text { Vizianagaram }\end{array}$ & $\begin{array}{l}\text { Delayed/unseasonal rainfall, temperature } \\
\text { fluctuations, low soil fertility }\end{array}$ \\
\hline Karnataka & 9.7 & $\begin{array}{l}\text { Kolar, Ramnagara, Tumkur, } \\
\text { Chikkaballapura, Dharwad }\end{array}$ & $\begin{array}{l}\text { Rainfed cultivation, low soil fertility } \\
\text { and moisture retention }\end{array}$ \\
\hline Bihar & 9.2 & $\begin{array}{l}\text { Darbhanga, Samastipur, } \\
\text { Muzaffarpur, East Champaran, } \\
\text { Vaishali }\end{array}$ & $\begin{array}{l}\text { Alternate bearing, unseasonal / } \\
\text { deficient rainfall, hail storms }\end{array}$ \\
\hline Gujarat & 7.9 & $\begin{array}{l}\text { Valsad, Navsari, Junagadh, } \\
\text { Surat, Kutch, Amreli }\end{array}$ & $\begin{array}{l}\text { Water stress, salinity and nutritional } \\
\text { deficiencies }\end{array}$ \\
\hline Maharashtra & 2.5 & $\begin{array}{l}\text { Ratnagiri, Sindhudurg, } \\
\text { Ahmednagar, Pune }\end{array}$ & $\begin{array}{l}\text { Hard lateritic, nutrient deficient acidic } \\
\text { soils, high humidity and heat stress in } \\
\text { Alphonso growing areas }\end{array}$ \\
\hline Odisha & 3.8 & $\begin{array}{l}\text { Dhenkanal, Rayagada, } \\
\text { Koraput, Kalahandi }\end{array}$ & $\begin{array}{l}\text { Acidic soils, rainfed production, } \\
\text { poor canopy management, cyclones / } \\
\text { hail storms }\end{array}$ \\
\hline
\end{tabular}

uneconomical. In North India, exhausted trees can be rejuvenated by severe pruning in winters for the production of new shoots, which can bear good crop in the following years.

The decline of productivity has been attributed to various factors. Most of the problems are due to faulty management i.e. poor land use planning for orchard establishment (unsuitable site and climate), cultivation of intercrops by removing the entire crop residues, inadequate nutrition, improper planning, undesirable planting materials, incidence of insect pest and disease and other biotic and a biotic stresses. A typical senile/declining orchard shows symptoms of i) Sparse appearance, ii) typically chlorotic/yellowing, unexplained types of foliage symptoms, iii) undergrowth and sickly appearance, iv) dried-up top growth v) small and less number of fruits. The branches of trees start to die from the top to downwards, trees loose biomass and starve from lack of carbohydrate, ultimately result in poor quality rough surface, thick skin and less juice fruits. Such type of decline may be seen in whole orchards, on in a single tree or patches. In orchards crossing the age of 30 years, it is a rare to get any plantation free of this malady. This intensity varies from plant to plant and from season to season in the same plant. The orchards become unproductive and sick because of lack of adoption of major operations such as canopy management, manuring, plant protection, irrigation, mulching, etc.. In general, canopy of fruits on trees has irregular shape. Trees of irregular shape and size are difficult to deal with and even culminate into poor yield in the subsequent years as the lower branches of canopy gradually turns inert and infertile as well. In Uttar Pradesh, and other northern plains the mango yields starts declining in 40-45 y old Dashehari trees (Lal and Mishra, 2008), but in late maturing Chausa, yield decline may begin in relatively younger plantations (30 y) (Lal and Mishra, 2007). In KonkanAlphonso, productivity diminishs in H" 30 y old trees. This is mainly attributed to canopy shading in older plantations (e" $60 \mathrm{y}$ ) reduced light penetration which results in very low yields $\left(\mathrm{H}^{\prime} 2.5 \mathrm{t} \mathrm{ha}^{-1}\right)$ (Burondkaret al., 2000). Similarly in rainfedareas of Karnataka, Alphonso orchards become less productive in H'25 years after establishment (Reddy and Kurian, 2011). In West Bengal, Himsagar orchards above 40 years age display very low productivity. About $30-40 \%$ of the orchards in traditional areas are believed to have gone less productive. Apart from yield the fruits borne on ageing trees may also be poor in bioactive compounds. For example the fruits from 
30-years old Amrapali trees had less total phenols, ascorbic acid and antioxidants (Meena and Asrey, 2018). This is attributed mainly due to poor exposure to sunlight. Only sun-exposed areas produce good quality fruit

\section{ii) Poorly managed high density orchards.}

High-density cultivation is the concept today to achieve higher productivity in short period. Crowding of plants is now considered an assured way of having a higher production. This is common in banana, papaya, pineapple. Apple and guava. However, in mango it is rather of recent development. An increasing number of farmers across the country have already started adopting high-density cultivation of mango. In a traditional matrix of 10 meter by 10 meter spacing in a hectare, 100 trees can be accommodated. However, in high-density planting, 1,600 trees of Alphonso or Amrapali variety can be planted. The yield of mangoes in the high-density system goes up to 18 tonnes per hectare compared to 6 tonnes for traditional planting. Certain ultra high-density mango cultivation on a commercial scale is also in place in Tamil Nadu.

However, mango experience is not as good as in case of papaya and banana. Mango is not as amenable for regular pruning as in guava and other fruit crops. Nutrient management under high density is also not well standardized. Due to irregular bearing habit of mango, though the claim on regular bearing is made, examples of alternate bearing is also equally reported. We are yet to minimize the unproductive components of plants without sacrificing the overall health of the tree through optimization of the parameters of growth in high density mango orchards. In the northern plains the HDPs of Amrapali in absence of annual pruning showed slow decline in yield after 15 years. Poor light penetration in HDPs (Fig 1) results in reduced availability of photo-assimilates adversely affecting vegetative growth, flowering and fruit set (Sharma and Singh, 2006). In another study 25 year old high density orchards of Mallika and Dashehari also exhibited marked reductions in productivity (Singh etal., 2010). In the southern region fifteen year experience of high density planting of Alphonso mango in IIHR is not as promising as that of a normal $10 \mathrm{~m} \times 10 \mathrm{~m}$ planting in practice with farmers of Karnataka. Averaged over first fifteen orchard years high density Alphonso mango with 1111 plants per hectare yielded 94.98 tonnes against 19.2 tonnes in $10 \mathrm{~m} \times 10 \mathrm{~m}$ check. When yearly average is calculated high density orchard yielded 6.3 tonnes and that of normal spacing 1.27 tonnes. Both the yields are extremely low indicating that the management in both high density as well as normal spacing orchards are extremely poor. The yields in other experimental density planting (400 and 178 plants per hectare) with dwarfing root stocks and paclobutrasol were also very poor. Hence this result of enhanced yield in high density orchards cannot be taken on its face value(Kurian 2016) because the national mango average productivity itself stood at 7.51tonnes per hectare in 2009-10, 8.56tonnes in 2014-15, 8.44tonnes in 2015-16 and 8.70 tonnes per hectare in 2016-17(NHB, 2018). A recent review of performance of high density mango orchards by Menzel and Lagadec(2017) has shown that trees planted at high density soon begin to crowd and shade each other and production falls. There has been no general agreement on the optimum planting density for commercial orchards which vary from 200-4000 trees per ha in different experiments. Some potential dwarfing material has been developed in India (like Vellikolulumban and Olour) and elsewhere, but these cultivars and rootstocks have not been widely accepted by farmers and nursery men and have not been integrated into high-density orchards. Canopy management needs to take into account the effect of pruning on the regrowth of the shoots and branches, light distribution through the canopy and the loss of the leaves that support the developing crop. Pruning must also take into account the effect of vegetative growth on flower initiation. Annual light pruning usually provides better fruit production than more severe pruning conducted less regularly. There have only been a few cases where it has been demonstrated that paclobutrazol can counteract the negative effect of pruning on flowering and fruit production. There are also concerns with residues of this chemical in export markets and contamination of ground waters. The productivity of mango is not likely to be increased by the use of high-density plantings without extensive efforts in canopy management.

\section{Rainfed situations -a reason for low productivity of mango}

Mango is basically a tropical and subtropical tree. It can grow best in these climatic conditions. Water and plant nutrients are the two key inputs enhancing the mango productivity. They need a good 
amount of rain during their growth period and a dry spell during the flowering period. However, a large hectarage of mango in India is under rainfed conditions. The trees withstand water deficit well but with appreciable reductions in fruit yield. It grows well both in low $(25 \mathrm{~cm})$ and high $(250 \mathrm{~cm})$ rainfall areas. In areas with high rainfall, mango orchard soils in many rainfed areas have low SOC, high run-off losses and low WHC as is seen in Subtropical foothill zones of north-western Himalayas (Rathoreetal. 2013), Eastern Ghats highland zone of Odisha (Swain et al., 2012), red and lateritic soils of Deccan plateau (Reddy and Kurian, 2011) and black clay loam soils of Madhya Pradesh (Tiwari and Baghel, 2015).

However, with annual rainfall around $75 \mathrm{~cm}$, it grows without irrigation. The mango flowers and fruits during dry season, which is characterized by absence of rainfall. Rain or cloudy weather at the time of flowering causes considerable damage to mango as it adversely affects flowering and fruit set and increases incidence of pests and diseases. In other words, it needs a good amount of rainfall from June to October and dry spell from November. Rainfall, high level of humidity or frost during flowering period may hinder the flower formation process. Availability of soil moisture and nutrients at critical stages of plant growth enhances the crop productivity. Drought during peak monsoon period affect biomass accumulation in the trees without which the tree does not enter into reproductive phase. Ultimately this leads to an "off" year. On the contrary in an "on" year if the rain or cloudy weather prevails at the time of flowering may become an "off" year due to considerable damage. This adversely affects flowering and fruit set and increases incidence of pests and diseases. During drought or deficit moisture the numbers, varieties and destructive power of pests increase, and there is a lack of effectivity of pesticides against them.

Many rainfed region mango farmers have gone for tube well irrigation to protect the trees. However, the main problem is that the farmers are facing water scarcity due to decline in ground water levels and water quality is also poor. There were no adequate rains for the last three years (2014-17) in main mango belts of Konkan, Chittoor, Krishnagiri, Nuziveedu, Sambalpur, Malda and Murshidabad, Saharanpur etc. due to which several farmers have ignored paying attention to mango orchards. This year (2018) untimely rains and gusty winds have damaged mango trees at several places.

\section{Changing climate has badly hit mango productivity}

Climate change is becoming an observed reality. It would be a tedious work to analyze and present the expected consequences of climate change on mango production and cultivation in all the mango regions of the country. Because of the vast number (20)of agroecological regions, it is not possible to draw a general scenario of these consequences because of regional and seasonal variability for the future climate, and likely different cultivar responses. However, they will be mostly negative and mango cultivation will experience more severe climatic conditions.

Climatic change and unseasonal rain regularly dampen the prospects of mango farmers in southern India. Late flowering and delayed fruit maturity and the resultant delay in harvest gets mangos caught in rains leading to very poor quality of mangos. On the other hand with the regularly prevailing severe cold, due and fog during the nights and increasing temperatures during the day, the mango flowering is subjected to damage in northern plains. However, throughout the country the rain and hailstorm accompanied by strong winds are another climatic factor severely damaging the yields of mango crop. The mango hoppers and the powdery mild dew are affecting mango flowers to a large extent and it is now a regular trend that the mango flowering being damaged. Under favorable season if the mango harvest is delayed and harvesting period penetrates into premonsoon period then there will be severe damage due to fruit fly and stone weevils. Apart from this mealy bugs and tearstains are on the increase leading to very poor quality fruits. An aberration in weather has started showing severe staggered flowering leading to irregular maturity time of fruits. Severity of the problem is such that even paclobutrasol applications fail to induce flowering. Recurrent flowering from January-April diverts assimilates towards the new panicles depriving the developing fruits. Although temperature extremes are causing the trees to flower repeatedly in my personal opinion it is singly caused by the insects damaging the vegetative parts of the plant on a regular basis predisposing trees to carbohydrate deficiency and ultimately leading to staggered flowering. About 
Table 5. Farmers perception of temperature changes in Konkan region (http://www.downtoearth.org.in)

\begin{tabular}{|l|c|c|c|c|}
\hline \multirow{2}{*}{ Month } & \multicolumn{2}{|c|}{ Maximum } & \multicolumn{2}{c|}{ Minimum } \\
\cline { 2 - 5 } & A decade ago & Now & A decade ago & Now \\
\hline January & $25-26$ & $32-33$ & $18-20$ & $14-15$ \\
\hline February & $27-28$ & $33-35$ & $20-21$ & $14-16$ \\
\hline March & $27-28$ & $36-38$ & $23-24$ & $17-18$ \\
\hline April & $31-32$ & $42-43$ & $28-30$ & $35-36$ \\
\hline
\end{tabular}

18 insects and 14 fungal and bacterial pathogens cause appreciable economic losses to mango in different growing regions.Farmers perception on temperature changes in Konkan region during mango season is given in Table 5.

In the past few years, the farmers are regularly incurring losses due to decline in the yield and due to poor quality of fruits. Some of our recent experiences are reported by Indian media. Briefly i) In Krishnagiri mango hub of Tamil Nadu, scorching heat waves decreased production by $50 \%$ in 2016 (https://www.deccanchronicle.com, ii) Extended winter, low night temperature and high day temperature have caused appreciable damage to mango crop in Andhra Pradesh in the last 2-3 years (http://www.thehansindia.com) iii) Heat stress dealt a severe blow to mango production in Maharashtra in 2017 (https:// timesofindia.indiatimes.com), Hailstorm and thunder showers spoiled about 50\% crop in Jeypore, Odisha in 2017 (http://www.newindianexpress.com), iv) Climate variability and heat stress in summer months have substantially trimmed mango growers' profits in Uttar Pradesh since the last few years (https:// scroll.in), v) Unfavourable weather conditions like cloudy weather during flowering badly hit 'Noor Jahan' grown only in Alirajpur district of MP in the last few years (https://www.hindustantimes.com), vi). In Konkan region, drop in temperature resulted in delayed arrival in 2010,2011,2012. There was a sudden drop in temperature in $2010-11$. This cold wave prolonged during $2011-12$ and 2016-17. Further the cold waves were very erratic. Ultimately these events resulted in a drop in heat units by 5.5- 4.2 degree days. As a consequence there was delay flowering, recurrent flowering, poor pollination and fertilization, severe fruit drop and delay in maturity.

\section{Soil related constraints, nutritional constraints and abiotic stresses}

Mango by the virtue of its perennial nature of woody framework locks major proportion of nutrients in stems, branches and leaves. Their extended physiological stages of growth, differential root distribution pattern, growth stages from the point of view of nutrient requirement and preferential requirement of some nutrients like calcium, boron etc., collectively make it nutritionally more efficient than any annual crops. Mango has the ability for colonization in low fertility soils and dry-land areas by virtue of long leaf life span, leaf nutrient resorption efficiency, nutrient use efficiency and nutrient proficiency(Ganeshamurthy and Reddy 2015). Mango is cultivated on all soil types like alluvial soils, red soils, laterite soils, black soils and both in hills and plains and plateau regions and on both shallow and deep rooted soils. However the productivity is dictated by the soil related constraints in these respective regions. Being a very hardy crop mango tolerates a varying degree of flooding, drought, salinity and acidity. This wide adoptability of mango is because of existence of both calcicole and calcifuge mangos in India and they occupy such regions suiTable to those genotypes. For example most of the southern states and Western states have calcifuge mangos like Alphonso, Badami, Totapuri, Bernishan, Kesar, Raspuri, Neelam, Sindhuraetc. which do not tolerate alkaline (basic) soil. While all north Indian mangos like dasheri, langra, chausa, amrapali, safedaetc are calcicole mangos which do not tolerate acidic soils. Though we find intermixing of these varieties these days, the productivity is affected by the respective soil constraints in their region. Some of the main constraints in different soil types are:

Alluvial soil : The main constraints in these soils include low content of N,P,S,Zn and organic matter 
and development of salinity and/or sodicity under injudicious use of irrigation water.

Red Soil : The main constraints in these soils include surface crusting and low soil depth under upland conditions. These soils are low in water holding capacity and have high soil-erosion potential and surface runoff. They have compacted subsurface layer due to illuviation, which may lead to restricted root development. These soils have low CEC and high $\mathrm{P}$ fixing capacity. These soils are low in N,P, $\mathrm{Ca}, \mathrm{B}, \mathrm{Zn}$ and $\mathrm{S}$.

Laterite soil : The major constraints of these soils are deficiency of $\mathrm{P}$ accentuated by high $\mathrm{P}$ fixing capacity of $\mathrm{Fe}$ and $\mathrm{Al}$ phosphates, high acidity, toxicity of $\mathrm{Al}$ and $\mathrm{Mn}$ and deficiency of $\mathrm{K}, \mathrm{Ca}, \mathrm{Mg}$, $\mathrm{Zn}$ and $\mathrm{B}$.

Black soil : The main constraints in this soil to mango production are due to low infiltration and poor drainage when wet leading to water logging and high runoff and soil loss during heavy downpour. Otherwise these soils suffer from moisture stress during drought. These soils are poor in organic carbon, nitrogen, sulfur and phosphorus. Water holding capacity is a major problem in shallow soils. Whereas deep soils when irrigated are very much prone to salinity and sodicity particularly in the subsoil. The calcareous nature of these soils affects the availability of many micronutrients particularly iron.

Generalizing these limitations we may face marginal to moderate sodicity and high $\mathrm{pH}$ in many parts of northern plains, soil acidity related constraints in mango belts of Maharashtra, Jharkhand and Odisha., soil and groundwater salinity in traditional (e.g., south Gujarat) and potential (e.g., Jalgaon, Haryana) mango growing belts. In Alphonso growing areas of Maharashtra, lateritic soils developed from basalt have poor fertility and low nutrient retention capacity. In red and lateritic soils of Deccan plateau, Karnataka, Tamil Nadu and in Eastern states, mango suffers from nutrient leaching, poor base status, acidity and low moisture retention capacity. However, in all the regions deficiencies of major (NPK) and some micronutrients $(\mathrm{Zn}, \mathrm{B})$ are the main yield limiting factors.

\section{Measures to enhance mango productivity under constraint environment}

\section{Conservation Horticulture in Mango Orchards}

Mango orchards in India are witnessing severe degradation of soil. Much of this degradation can be attributed to common, but exploitative, orchard management practices like repeatedploughing that destroys the soil structure and degrades organic matter, burning or removing crop residues from the orchards, mono-cropping with single variety. Soil and water management practices that sustain and enhance the productivity of orchard soils are a must and are a vital part of the long-term solution to enhance mango productivity.

Conservation horticulture is a new concept in management of soil health under perennial horticultural cropping systems. Conservation horticulture aims to overcome these problems by addressing the four basic principles a) disturb the soil as little as possible b) keep the soil covered and c) mix and rotate crops and d) conserve the soil moisture. Experiments conducted reasonably over a long period on such soil management systems provide valuable information about sustainability of production systems. Conservation horticultural practices improved the quality of soil, especially near the surface, by lowering the bulk density and enhancing infiltration rate. The soil aggregate formation and water stability have enhanced in plots with conservation practices because of higher production of glomalin compared with vegeTable and orchard plots where conventional practices were followed. Relationship between measured infiltration and soil properties showed high average infilteration rates in conservation plots due to high organic matter content, low bulk density values and enhanced exchangeable basic cations(Ganeshamurthyetal 2016b). Vegetable plots and conventional mango plots showed complete decline in earthworm and centipede population while plots with conservation practices showed a build-up of their population. Microbial and biochemical properties significantly improved in plots with conservation horticultural practices over orchard plots with conventional practices. Legumes as inter and cover crops were found to be superior in improving soil quality than sweet potato. These interventions ultimately enhanced the mango productivity and profitability (Ganeshamurthyetal., 2018).Farmers 
throughout the country are beginning to adopt them; they have seen their yields rise, their soil gain in health and fertility, and their labour needs reduced. Conservation horticulture must be promoted actively if it is to be spread rapidly. Grass root players (farmers, extension workers, input suppliers, etc.,) often lack information on what, when and how to do it. The intercrops recommended/adopted in different mango growing regions are listed in Table 6. The extension agencies must create massive awareness programme to promote conservation horticulture in mango.

\section{Mango on marginal lands: Measures to sustain and enhance yields}

Several examples of mango cultivation on marginal lands are available. Most of these are farmerled innovations. Typical among them is the rock blasting'. Practiced in Konkan region for Alphonso mango cultivation on degraded laterite soils. The system of planting Alphonso mango on these exposed, barren laterite rocks (qualifying as wastelands, termed Jambhadagad locally) of Konkan region, is a successful soil management module developed by local farmers, in practice for decades now. In this method, existing native trees are cleared followed by blasting of below ground hard surfaces (locally called jambhadagad) to create bowl-shaped pits that are filled with non-native soils to overcome the nutritional constraints in the local acidic soils. This is a unique model for sustainable development of Wasteland with Tree-based farming System under a very fragile ecosystem of Western Ghats under high intensity and heavy rainfall. Using this technology, over 130,000 ha hard lateritic lands in Ratnagiri, Sindhudurg and Raigad districts have been put under Alphonso cultivation. After planting, due care is necessary for soil placement around saplings for the proper development of feeder roots. Today the mangoes grown in the district of Ratnagiri and Sindhudurg carry the GI tag and are marketed as the very special RatnagiriAlphonso or Haapoos. In fact, farmers from these two districts created a "Market Brand"and have been awarded with Global Good Agricultural Practices (GAP) certificate that enables them to export their mangoes.

\section{Cultivation of mango on acidic soils}

A large area of mango in southern states, eastern states and western ghats is on acidic soils. These orchards productivity are low as they face several challenges. Management of acid soils should aim at realization of production potential either by addition of amendment or manipulation of agricultural practices. In the uplands where mango crops dominate, soil acidity is caused mostly by leaching losses of bases and high percolation of water. This creates problems of crust formation particularly in light textured red soils. The common problems for mango production on such soils are low $\mathrm{pH}$, low $\mathrm{CEC}$, high concentrations of $\mathrm{Al}$, Fe and Mn, nutrient imbalance, low level of base saturation, high $\mathrm{P}$ fixation and domination of low activity clays.

Liming : One of the most common practices to overcome the problems of soil acidity for fruit production is liming the soil to correct soil $\mathrm{pH}$. Before undertaking liming, one must decide whether to correct soil $\mathrm{pH}$ or to reduce some of the toxicities associated with soil acidity and overcome deficiency of some of the nutrient elements. There are five guidelines that help us determine the lime requirement: i) the orchard to be limed, ii)the desired change in $\mathrm{pH}$, iii) buffering capacity of the specific soil, iv) type of liming material, and v) the fineness or texture of the liming material. To avoid aluminum and manganese toxicity problems, a soil should be limed if the $\mathrm{pH}$ is less than 5.5. Since finer textured soils have greater buffering capacity than coarser textured soils, more lime must be added to the finer textured soil to achieve the same effect and reach the target $\mathrm{pH}$ (Ganeshamurthyetal.2016d). Liming soils under mango can also be accomplished with surface application with little or no tillage. Irrigation and rainfall slowly leaches the lime, which is relatively insoluble, from the surface into the soil profile where it can react to neutralize soil acidity. Using the proper fertilizer formulation is an important way to manage soil acidification where liming is less easily incorporated than in annual or short-term systems. Periodic soil testing is recommended for amended soils. Soil test results provide the current soil $\mathrm{pH}$ information and indicate whether there is a need for further addition of lime, sulfur or dilute acids. Acid neutralization takes time, so lime should be applied to acidic soils 3-6 months prior to planting or seeding. Over the course of the growing season, the $\mathrm{pH}$ of the limed soil may change back, therefore periodic soil testing is recommended.

Fertilization : Macronutrient applications, can significantly adjust soil $\mathrm{pH}$ in the root zone instead of the whole plough layer. Nutrients can change soil $\mathrm{pH}$ 
differently depending on the electric charge of the nutrient ions. There are two types of nutrients: positively and negatively charged. The positively charged nutrients include ammonium-nitrogen, potassium, calcium and magnesium, etc. All of these nutrients may reduce soil $\mathrm{pH}$ in the root zone. Hence such fertilizers should be avoided. The negatively charged nutrients include nitrate, phosphate, and sulfate, etc. All of these nutrients may increase the $\mathrm{pH}$ in the root zone. Such fertilizers must be promoted for mango on acid soils.

Promotion of micorrhiza and biofertilizers : Mycorrhiza plays an important role in acquisition of nutrients particularly $\mathrm{P}, \mathrm{Zn}$ and other micronutrients. Inoculation of seedlings at nursery stage helps in better root colonization in establishment of mycorrhiza. However with the new technology developed at IIHR, mycorrhiza inoculums may also be applied to trees in orchards to colonization in established orchards. In addition to this, nutrient mobilizingbiofertilizers like Arka Microbial Consortium(AMC) developed by IIHR is performing extremely well in mango orchards in better acquisition of nutrients. Such effective biofertilizers must be promoted for enhancing the productivity of mango on acid soils.

\section{Prospects of Mango on salt-affected soils:}

Secondary salinization (due to anthropogenic activities such as irrigation) may occur by improper management of irrigation. Crop yields are drastically affected due to lack of availability of water, nutrients, and oxygen in the root zone. The magnitude of yield reduction depends on the crop, soil type, and management. The reduction in yield normally ranges from $10 \%$ to $90 \%$ for wheat, $30 \%$ to $50 \%$ for rice, $50 \%$ to $75 \%$ for cotton, and $30 \%$ to $90 \%$ for sugarcane. Crop yield can be enhanced by nutrient management (especially $\mathrm{N}$ ), water management (irrigation with good quality water and appropriate drainage), use of soil amendments (manures and gypsum, etc.), and use of salt-tolerant varieties.

Major factors causing salinity development in mango orchards are summarized in the following.

Water shortage for irrigation : Salt-affected orchards are mainly located in semi-arid and lowland dry areas, where rainfall is neither sufficient nor reliable for sustainable mang production. In these areas, irrigation is necessary for stabilizing production. In many orchards in Indo GangeticPlane, farmers use flood irrigation.

However large tracts of mango orchards depend upon tubewells for irrigation. Declining water Table, deteriorating irrigation water quality leads to salinization of orchard soils. Development of soil salinity in this area is often associated with use of poor quality water for irrigation. There is a drastic increase in the chloride and bicarbonate content of the tubewell waters which affect mango yields very badly. In such areas gypsum application, raised beds, salt tolerant rootstocks, mulching and drip irrigation, crop residue recycling, rainwater harvesting to leach salts during summer months are suggested. In Jalgaon, improved management led to the successful hi-tech mango orcharding in problem area of salinity and fresh water scarcity (Krishna etal., 2009). Salt tolerant rootstocks like 13-1 may be used to sustain mango cultivation in salt-affected soils. Such work have been initiated at Kurukshetra and Centre of Excellence for Mango at Gir.

\section{Watershed approach for enhancing mango productivity in wastelands}

Mango is suiTable for colonization in waste lands, low fertili ty soils and drylands(Ganeshamurthy and Reddy, 2015). If wasteland is developed under watershed model then mango is a candidate crop for promotion. The national bank for agriculture and rural development(NABARD) under Wasteland Agriculture Development Initiative (WADI), has been promoting mango cultivation on wastelands in tribal areas. Wadi (meaning small orchard) constitutes the core of the WADI program around which other development interventions are strengthened. Under this programme tribal families having Â 2 ha of land are selected for holistic land development plans including soil and water conservation measures. Minimal soil disturbance, improved orchard floor management and prevention of uncontrolled grazing lead to SOM accumulation, weed control, C-sequestration, nutrient recycling and improved soil structure while curtailing the production costs and enhancing the fruit yield. Promotion of mango farming under WADI has led to manifold increase in farm incomes in many tribal areas of country with simultaneous improvements in soil quality (www.nabard.org). Under tribal sub plan (TSP) IIHR under its sub station CHES Bhuvaneshwar has 
promoted Amrapali mango plantations in tribal areas of Orissa. With the practice of modern management practices, Amrapali mango in these tribal area recorded very high productivity and helped in improving their economic conditions multiple folds. So far NABARD has implemented 51 WADI projects in 17 tribaldominated districts.

\section{Mango-based Agro-forestry systems : for efficient utilization of interspaces}

Under the present scenario of natural resource degradation and climate change, the potential of trees holds promise to bring improvements in nutrition, income, housing, health, energy needs, and environmental sustainability in the agricultural landscape, with the presence of trees being the principal component. Mango can be the best candidate tree species for an agroforestry model. Mango plants start bearing 4-5 years after planting and attain full bearing capacity usually after 10 years. Widely spaced orchards $(10 \times 10 \mathrm{~m})$ provide ample scope for growing short duration crops for harnessing the productivity of interspaces. Crop duration, compatibility with mango trees and market demands influence farmers' decision making in intercrop selection. Short duration, locally adapted leguminous crops providing higher net returns should be taken as subsidiary crops for year-round cash flow and improvements in soil quality, enhancement in biodiversity and an overall benefit to main mango crop through several ecosystem services. Here the basic principle of "Conservation horticulture" is

Table 6. Intercrops recommended/adopted in different mango growing regions

\begin{tabular}{|c|c|c|c|}
\hline Region & Agro-climatic conditions & $\begin{array}{l}\text { Orchard } \\
\text { characteristics }\end{array}$ & $\begin{array}{l}\text { Intercrops } \\
\text { recommended/adopted }\end{array}$ \\
\hline \multirow[t]{2}{*}{$\begin{array}{l}\text { North Western } \\
\text { Region }\end{array}$} & $\begin{array}{l}\text { Humid subtropical; sandy } \\
\text { loam soils (pH 6.5-7.0) }\end{array}$ & $\begin{array}{l}\text { Cv. Mallika } \\
8 \times 8 \mathrm{~m}\end{array}$ & $\begin{array}{l}\text { Cowpea-toria and okra-toria } \\
\text { rotations in pre-bearing phase }\end{array}$ \\
\hline & & & $\begin{array}{l}\text { Turmeric and colocasia in } \\
\text { bearing orchards }\end{array}$ \\
\hline $\begin{array}{l}\text { North Eastern } \\
\text { Himalayas }\end{array}$ & $\begin{array}{l}\text { Humid subtropical; sandy loam } \\
\text { acidic soils ( } \mathrm{pH} \sim 5.5 \text { ) }\end{array}$ & $\begin{array}{l}\text { Cv. Kalcho } \\
8 \times 8 \mathrm{~m}\end{array}$ & $\begin{array}{l}\text { Cowpea, roselle, French bean, } \\
\text { pineapple and turmeric in bearing } \\
\text { orchards }\end{array}$ \\
\hline \multirow[t]{2}{*}{$\begin{array}{l}\text { Indo-Gangetic } \\
\text { plains }\end{array}$} & $\begin{array}{l}\text { Humid subtropical; sandy } \\
\text { loam slightly alkaline soils }\end{array}$ & Cv. Dashehari & $\begin{array}{l}\text { Brinjal and bottle gourd in } \\
\text { pre-bearing orchards }\end{array}$ \\
\hline & Humid subtropical & Cv. Dashehari & Wheat, brinjal and potato + pumpkin \\
\hline $\begin{array}{l}\text { Central India } \\
\text { (Mandsaur) }\end{array}$ & Rainfed, black clay loam soils & $\begin{array}{l}\text { Cv. Dashehari } \\
7 \times 7 \mathrm{~m}\end{array}$ & $\begin{array}{l}\text { Companion intercropping of pigeon } \\
\text { pea + soybean; sequential } \\
\text { intercropping of cowpea-chickpea }\end{array}$ \\
\hline \multirow{3}{*}{$\begin{array}{l}\text { Deccan plateau } \\
\text { phase }\end{array}$} & Rainfed lateritic coastal soils & 3-years old trees & Green chilli and palak in pre-bearing \\
\hline & Semi-arid red soils & Pre-bearing & Brinjal-onion rotation \\
\hline & Sub Humid red soils & 35 year Alphonso & $\begin{array}{l}\text { Cow pea, Sweet Potato, Mucuna } \\
+ \text { Pumpkin, Sweet corn, Niger, } \\
\text { Ground nut }\end{array}$ \\
\hline $\begin{array}{l}\text { Eastern Ghat } \\
\text { Highland Zone }\end{array}$ & $\begin{array}{l}\text { Rainfed uplands; sandy clay } \\
\text { loam soils (pH 6.3) }\end{array}$ & $\begin{array}{l}\text { Cv. Totapuri } \\
10 \times 10 \mathrm{~m}\end{array}$ & $\begin{array}{l}\text { Guava as filler tree and cowpea/ } \\
\text { French bean as intercrops }\end{array}$ \\
\hline \multirow[t]{2}{*}{ Western India } & Rainfed light soils & $\begin{array}{l}5-6 \text { y old trees } \\
10 \times 10 \mathrm{~m}\end{array}$ & Soybean-mustard sequence \\
\hline & $\begin{array}{l}\text { Rainfed plains zone of } \\
\text { Western Maharashtra }\end{array}$ & Cv. Kesar & $\begin{array}{l}\text { Minor millets and pulses up to } \\
5 \text { years }\end{array}$ \\
\hline
\end{tabular}

Source: Rathoreetal.(2013), Sahoo (2016), Singh etal.(2015), Singh etal.(2008), Tiwari\&Baghel (2015), Rao \&Rao, (2007), Sarkaretal.(2004), Swain etal.(2014), Ganeshamurthyetal. (2016) Pawar\&Sarwade (2006), Bhosaleetal.(2016). 
adopted in principle to overcome the problems of resource degradation by addressing the four basic principles a) disturb the soil as little as possible b) keep the soil covered, c) mix and rotate crops and d) conserve the soil moisture. It has been seen at several places that by practicing mango based agroforestry systems the productivity of mango orchards have shown very promising improvement over conventional commercial orchards. A compilation of the intercrops and cover crops recommended for different orchard conditions and different regions are presented in Table 6.

\section{Integrated mango-fodder production : a success story}

ICAR- IIHR, Bengaluru and ICAR-IGFRI RRS Dharwad have popularized intercropping of fodder crops in mango orchards. Besides improved fodder availability, this initiative has led to multifarious benefits in terms of reduced temperature stress, a significant decrease in weed intensity, and reduction in soil erosion. Apart from this a considerable decrease in pest-disease infestations and improvement in water penetration has been obtained. After the demonstration the perception of farmers on this benefit was recorded and is as under (Table 7)

Table 7. Farmer's perception on benefits of intercropping fodder in mango orchards (Source: Interaction with practicing farmers by authors)

\begin{tabular}{|l|l|l|}
\hline On mango orchard & On livestock rearing & On farmers \\
\hline Orchard temperature reduced & $\begin{array}{l}\text { Expenditure on feed decreased } \\
\text { by half }\end{array}$ & Knowledge on fodder crop improved \\
\hline Weed intensity reduced & Increased milk by 0.931 & Improved access to information \\
\hline Soil erosion reduced & $\begin{array}{l}\text { Distance saved to fetch } \\
\text { fodder 1.42Km }\end{array}$ & $\begin{array}{l}\text { Improved access to seed/ } \\
\text { propogation material }\end{array}$ \\
\hline Water penetration improved & Labour saved 0.91 mandays & Improvement in family nurishment \\
\hline Reduced pest incidence & & \\
\hline Reduced disease incidence & & \\
\hline
\end{tabular}

\section{Water harvesting technologies for supplemental irrigation}

Mango in rainfed areas face water shortage during critical stages. Harvesting of rain water holds promise to provide the much needed water at critical growth stages of mango and/or crops grown on orchard floors. Several examples of success of rainwater harvest under mango systems have been reported. In Chittoor (Andhra Pradesh), farm pond water is used for supplemental irrigation in mango (Kumar etal., 2016). Similarly in a one hectare model 35 year old Alphonso mango based farming system developed at IIHR, Bengaluru under NICRA has shown that it is possible to harvest water received during early monsoon period for irrigating intercrops during mid monsoon dry periods. Further the water harvested from the rains received during receding SW monsoon and further during cyclones during NE monsoon benefit the crops during post monsoon period (Manjunath etal.2018-NICRA work). In hot semi-arid areas of Karnataka micro-catchments constructed in half-moon shape (semi-circular) across mango trees capture surface runoff. Such constructions have resulted in yield enhancement by over $22 \%$ (Ali et al. 2017). In a HDP $(5 \mathrm{~m} \times 5 \mathrm{~m})$ of ArkaNeelachalKesri in Eastern India, cup-and-plate system of rainwater harvesting and mulching with paddy straw has resulted in maximum increase in fruit yield (Samant et al. 2015). Such several ways of rainwater harvested in mango orchards are in place in several regions. 'Jalkund', a rainwater harvesting structure $(8.0 \mathrm{~m}$ long, $6.0 \mathrm{~m}$ wide and $1.5 \mathrm{~m}$ high) can store $\mathrm{H}$ "72,000 1 water for irrigating H"0.2 ha crop area through drip. Such practices can result in exceptional benefits through enhanced productivity of mango and intercrops as well (Verma et al. 2013).

Insitu moisture conservation in orchard also facilitate in achieving more fruits per drop of water. Mulchingwith farm wastes or polythene improves soil moisture availability, moderates soil temperature, reduces the erosive impact of rainfall, suppresses weed growth and improves SOC after decomposition. In Gulabkhas plantation on an acidic (pH: 5.2) red lateritic soils of Odisha mulching with paddy straw or grass 


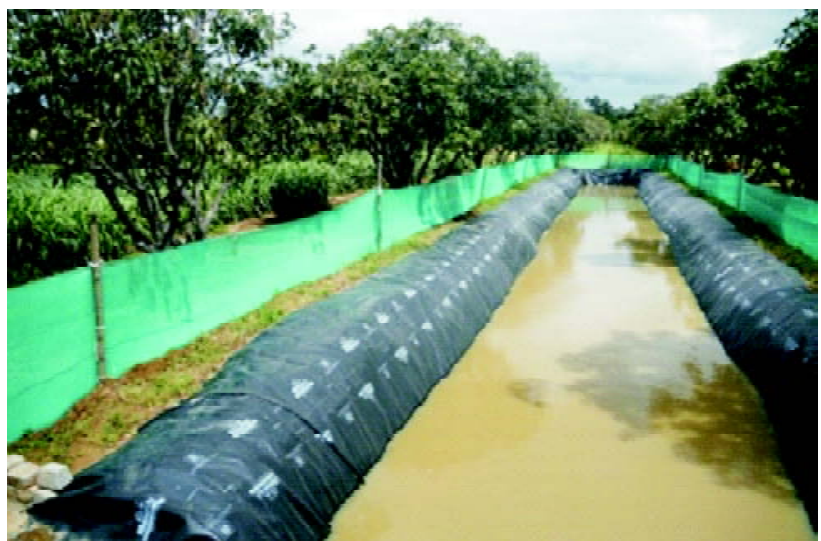

Fig. 5. Jalkund

(each at $1 \mathrm{~kg} \mathrm{~m}^{-2}$ ) enhanced soil moisture availability and fruit yield (Kumar et al.2008). Further at Mohanpur, West Bengal, organic mulching and deficit irrigation (30 1 water tree ${ }^{-1}$ at 10 days interval) increased Amrapali fruit yield by 2.5-times over control (Singh etal.2014). Similarly mulching and pre-harvest sprays together can extend the quality and storability of mango fruits. Borax (1.0\%) spray and polythene mulch improved yield and quality (TSS and total sugars) of Dashehari fruits. Substitution of borax with $\mathrm{CaCl}_{2}(2.0 \%)$, however, was better in extending the fruit shelf-life by arresting the physiological loss in weight (PLW) (Singh etal.2012).

Pitcher irrigation : It is probably the poor farmers drip irrigation, but less expensive to install. The pitchers are the round earthen containers used in rural areas for water storage, ranging from 10 to 20 liters in capacity. This is a highly efficient traditional method in which unglazed porous earthen pots containing water are buried under the soil to provide controlled irrigation to plants. Water slowly moves out through the wall to meet the plant's water requirement. In certain cases, pitcher irrigation may outperform drip irrigation in WUE. This kind of irrigation is ideal for establishing orchards for saplings, promoting deep root growth and to supply water at critical stages to crops during drought. It is also very good irrigation. Soluble fertilizers can also be mixed with water and applied through the pitcher as fertigation. It can also permit sustained use of saline irrigation water. Pot irrigation and mulching with coconut husk/crop residues is a popular practice for raising mangoes in parts of rainfedAlfisols of southern India. If the water used for irrigation has high salinity, the pitcher location should be changed every 3 years. To increase the depth of irrigation, a

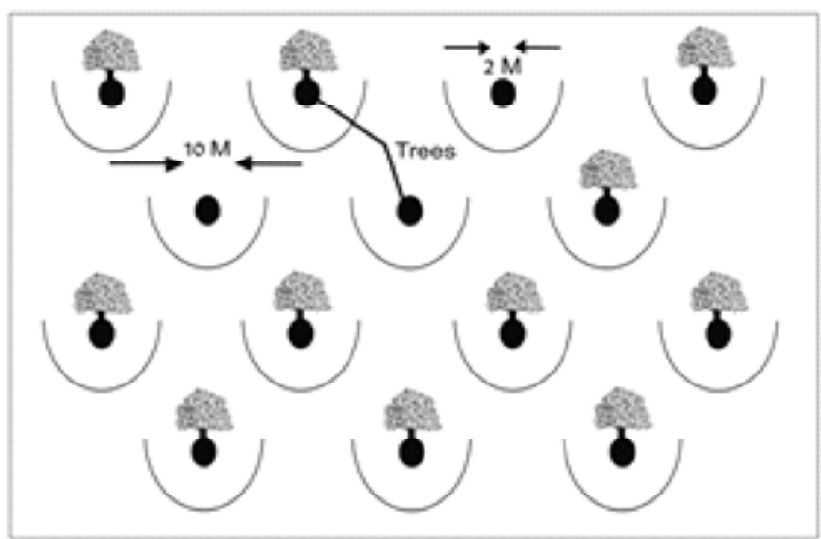

Fig. 6. Half-moon shaped micro-catchment

wick can be added to the pitcher. A study conducted at Rahuri revealed that provision of 2 pitchers of 41 capacity and 2-days irrigation interval was superior over other treatments with regard to in situ establishment of mango rootstock. Pitcher irrigation ensured 96\% survival in mango saplings of cv. Kesar under south Gujarat. Provision of one pitcher of 101 capacity filled weekly could save as much as $50 \%$ irrigation water.

Drip irrigation and fertigation : Irrigation to mango crop is still under controversial situation in India. Generally, it is taken for granted that mango tree does not require an irrigation and can survive on rainfall (700 to $800 \mathrm{~mm}$ during June to September).However, irrigation to mango orchards has shown the beneficial effect that the tree bears fruits earlier i.e. 6 year onwards the number of fruits and fruit size is increased. Similarly the effective fertigationprogramme of giving NPK nutrition becomes easier through drip irrigation. Management of drip irrigation is of prime importance in mango orchards. As drip irrigation is new and advanced method, its proper management is a very important aspect. In drip irrigation, the drippers operate at a slow rate; usually the discharge matches the soil infiltration rate which neither allows surface flooding nor the runoff, making water losses minimal. Fertilizers and nutrients are also applied through this system and their losses made minimal by localized application and reduced percolation. The system can irrigate irregular shaped fields and orchards on sloppy land without leveling the land as it is a prerequisite for basin, border and furrow irrigation methods. It also minimizes soil erosion and labour cost by regulating water through valves and drippers. The foliage remains dry thus reducing the risk of diseases. This method is usually 
operated at lower pressure than other types of pressurized irrigation systems such as sprinkler, thus energy costs are also reduced. Drip irrigation of mango invariably followed with fertigation. This benefited mango with timely supply of plant nutrients in required proportions. Some of the experiences of drip irrigation in mango is listed in Table 8. These experiences at different locations fortifies that drip irrigation can benefit mango in enhancing the productivity and enhancing the WUE.

Deficit irrigation(DI) and Partial root zone drying(PRD): DI is defined as an irrigation method in which the entire root zone is irrigated with a smaller amount of water than the prospective evapotranspiration (English and Raja, 1996). Whereas partial root zone drying (PRD) is a novel and innovative water-saving irrigation strategy that has been developed and tested in fruit crops. Deficit Irrigation (DI) and PRD have been applied to many crop species. The stress that develops has minimal effects on the ultimate yield of the crop. PRD is therefore a modification of DI whereby half of the root zone is irrigated while the other half is allowed to dry out (Fig. 7).

In alternate partial root zone drying irrigation (APRDI), the treatment is then reversed during the next irrigation cycle depending on the soil and climatic conditions, so that the formerly wetted part of the root system is allowed to dry to a predefined soil moisture

Table 8. Experiences of drip irrigation for higher fruit yield and better WUE.

\begin{tabular}{|c|c|}
\hline Region & Finding \\
\hline Central Indo Gangetic Plain & $\begin{array}{l}\left.\text { Fruit yield was much higher ( } 5.4 \mathrm{t} \text { ha" }{ }^{\prime \prime}\right) \text { in fertigation treatment compared to } \\
3.6 \mathrm{t} \text { ha"1 when NPK was applied in tree basins. }\end{array}$ \\
\hline Odisha & $\begin{array}{l}\left.\text { DI at } 80 \% \text { WR and black plastic mulch resulted in the highest fruit yield ( } 15.8 \text { tha }^{-1}\right) \\
\text { in an Amrapali } \mathrm{HDP}(5 \times 5 \mathrm{~m}) \text { in clay loam soils. DI at } 60 \text { and } 80 \% \text { WR led to the } \\
\text { maximum WUE and the highest B: C ratio, respectively. }\end{array}$ \\
\hline Chhattisgarh & $\begin{array}{l}\text { Maximum fruit yield and WUE in } 15 y e a r s \text { old Dashehari orchard, } 122 \% \text { higher than } \\
\text { in basin irrigation, was recorded in DI at } 60 \% \text { WR. }\end{array}$ \\
\hline Andhra Pradesh & $\begin{array}{l}\text { DI at } 75 \% \text { WR coupled with the application of } 100 \% \text { NPK }(100 \mathrm{~g} \text { each }) \text { and } 75 \mathrm{~kg} \\
\text { FYM tree }{ }^{-1} \text { led to the highest net income in a Kesar HDP }(6 \times 5 \mathrm{~m}) \text { in } \\
\text { semi-arid Alfisols }\end{array}$ \\
\hline $\begin{array}{l}\text { Tamil Nadu and Karnataka } \\
\text { under Project Unnati }\end{array}$ & $\begin{array}{l}\text { Ultra High Density Plantation with } 700 \text { trees per acre (UHDP), the water use per tree } \\
\text { is limited to } 30-35 \text { litres per month in the peak growing season of April-May. These } \\
\text { modern techniques are expected to enhance the produce by as high as } 200 \% \\
\text { compared to traditional plantation methods. }\end{array}$ \\
\hline
\end{tabular}
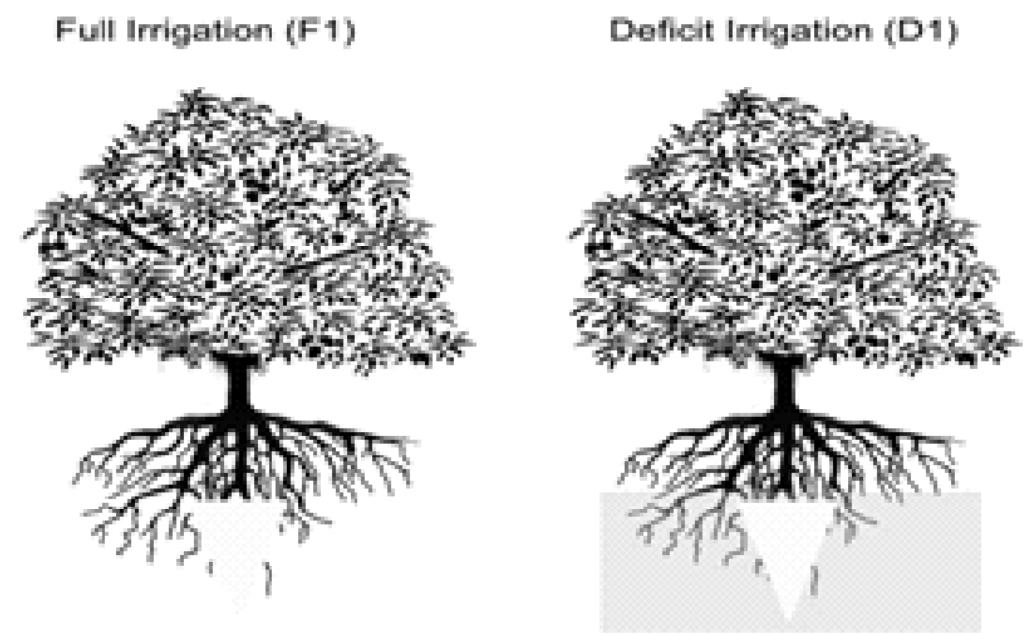

Partial Root -zone Drying (PRD)

Fig. 7. Schematic representation of deficit irrigation and partial root zone drying 
content and the dry part is allowed to be irrigated (Stoll et al., 2000). In fixed partial root zone drying irrigation (FPRDI) the irrigation water is applied to a fixed root side during the entire growing season while keeping the other side in a dry condition. A goodnumber of research has been carried out to study the effects of PRD on yield, water use efficiency, quality and production of mango. Recently, some studies have shown that irrigation water volumes in mango orchards can further be reduced by adopting deficit irrigation (DFI) and partial root zone drying (PRD) techniques. DI seems to be quite useful in semi-arid and humid areas where rainfall can meet crop WR at critical stages and also leach the salts accumulated during the irrigation season. Less utility of DI in arid climates emanates from the fact that salinity may develop even with the prolonged use of fresh water. In PRD, only half of the root-system is irrigated while the rest half is kept dry. Compared to control (irrigation at $100 \%$ of ETc), PRD and DI methods of irrigation (50\% of ET in each) led to much higher WUE in 14-years old 'Chok Anan' trees in Regosols (high stone content, low WHC) of Thailand. Due to marginal yield reduction, trees in deficit irrigation treatments showed considerably higher WUE reflecting water saving of 30-50\% (Spreeret al., 2009). In semi-arid Bahia region of Brazil (H"650 mm annual rainfall), RDI (50\% $\mathrm{ET}_{\mathrm{c}}$ ) in 9-y old Tommy Atkins trees $(8.0 \times 8.0 \mathrm{~m}$; sandy loam eutrophic FluvicNeoSol) did not affect fruit productivity and quality (Cotrimetal.2011). SDI treatment providing $50 \%$ of ET is recommended for the higher yield (18.4 $\left.\mathrm{t} \mathrm{ha}^{-1}\right)$ and WUE $\left(7.14 \mathrm{~kg} \mathrm{~m}^{-3}\right)$ in coastal Mediterranean areas of Spain (Zuazoetal.2011). We lack in such information from India. There is need to generate information on DI and PRD in mango for better utilization of available water.

\section{Nutrient Management - DRIS norms}

Several approaches are being adopted for nutritional diagnosis of fruit crops using leaf analysis including the critical value approach (CVA) and the sufficiency range approach (SRA) and the recent being the Diagnosis and Recommendation Integration System-DRIS (Beaufils, 1973). DRIS uses nutrient ratios and the nutritional balancing concept for interpretation of tissue analysis. This method is more precise in the detection of nutritional deficiencies or/ and excesses (Beaufils, 1973). The DRIS can also detect cases of low yield due to nutrient imbalance, even when none of the nutrients is below the critical level through an imbalance index (Baldock and Schulte, 1996). This method also has the ability to diagnose the plant nutrient needs much earlier in the life of the crop than the critical level method allowing remedial steps to be taken earlier with greater accuracy while providing a means of simultaneously identifying imbalances, deficiencies and excesses in crop nutrients and ranking them in the order of importance. DRIS and CND norms have been developed for important commercial varieties ((Raghupathietal. 2005; Raj and Rao, 2006). A typical representation of the principle on which DRIS is based is presented in Fig.8. This is

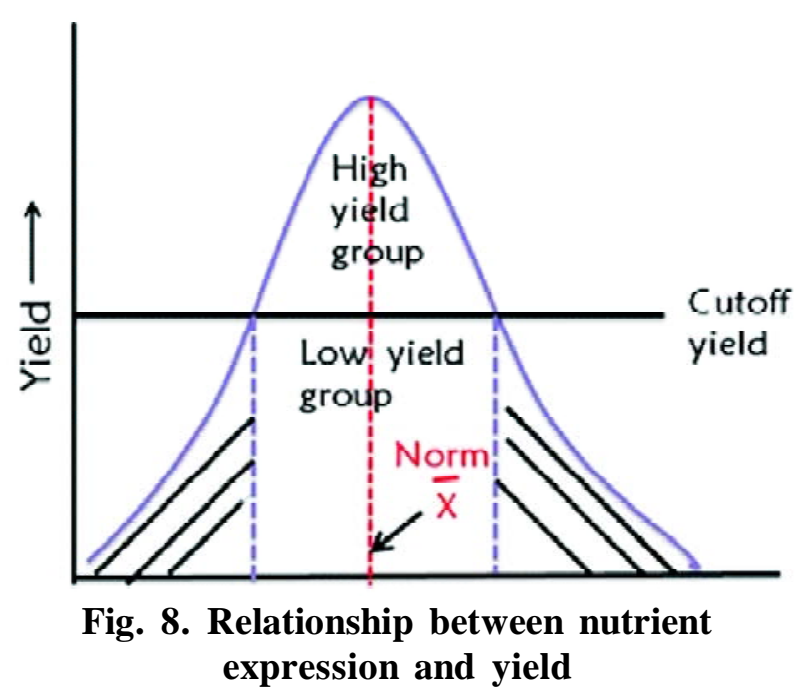

based on the division of population into high yielding and low yielding orchards on a generalized cutoff yield level of the crop. Nonetheless, this approach suffers from some limitations and may not provide valid results. Despite this mango researchers are increasingly using DRIS for optimum nutrient management in mango. However, DRIS enables the simultaneous identification of nutrient imbalances, deficiencies and excesses fairly independent of leaf age and other effects. DRIS indices more precisely detect yield limiting nutrients compared to the conventional critical nutrient concentrations (range) method and are found to be sensitive to both long- and short-term fertilizer management practices.

\section{Secondary and Micronutrient management} Calcium

Calcium is relatively a low mobility element in plant tissues. Hence the deficiency symptoms of this element are first seen in young leaves. In other species, 
the calcium deficiency symptoms are similar to those of boron, although they show a better distribution between young and old leaves. Calcium deficiency symptoms in mango is seldomly observed since the availability of calcium in soil in most cases is not restricted and it is supplied through application of mineral and organic fertilizers.Calcium deficiency is expressed as initial cupping of young leaves with marginal necrosis (Fig. 9 A \& B), poor fruit set and retention and severe fruit drop. Since calcium is involved in mobility of boron in plants, deficiency of calcium and boron often overlap (Ganeshamurthy et al. 2016a).

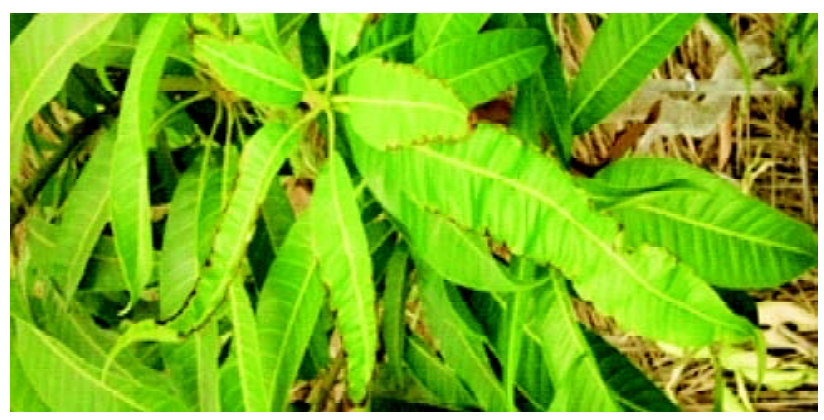

A

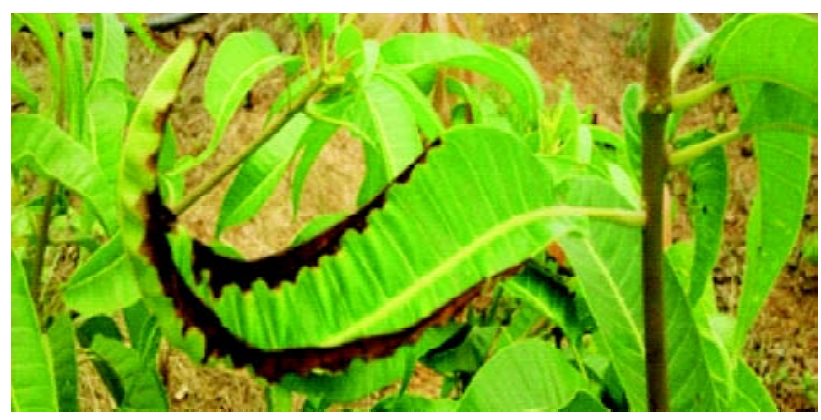

B

Fig. 9.Showing calcium deficiency in mango. Symptoms first appear on young leaves with fading of green colour. Growth is stunted. Leaf tip remains green and with severe deficiency the whole leaf turns yellow.

\section{Magnesium}

Magnesium being a part of the chlorophyll is basically involved in photosynthesis. Relative to other major fruit crops, mango is a very magnesium demanding crop. An adequate magnesium supply ensures sufficient sugar production and translocation to the developing fruit. Hence, it plays an important role in mango fruit quality, as the edible portion of the mango fruit contains approximately $15 \%$ sugar. The tree requires magnesium for optimal root growth, especially during the unbearing phaseand underdeveloped root systems are more prone to nutrient deficiency and water stress. Because of this magnesium influences the yield potential of trees. The optimum leaf concentration for $\mathrm{Mg}$ should be in the range $0.15-0.4 \%$ of dry matter. Symptoms of deficiency (Fig. 10 A,B,C)) first appear on recently matured leaves with fading of green colour. Chlorosis starts from leaf tip and spreads along the margins inwards in an inverted "V" shape. Under severe deficiency the leaves have yellowish brown chlorosis and premature defoliation. Tree growth becomes stunted and fruit yield and quality in terms of fruit colour, shape and size gets reduced. In northern plains where there is excess calcium in soil, magnesium deficiency is expressed as leaf bronzing starting from the edge of the leaf rounded margin between each pair of lateral veins exhibiting a green wedge down the central part (Ganeshamurthy et al. 2016a).

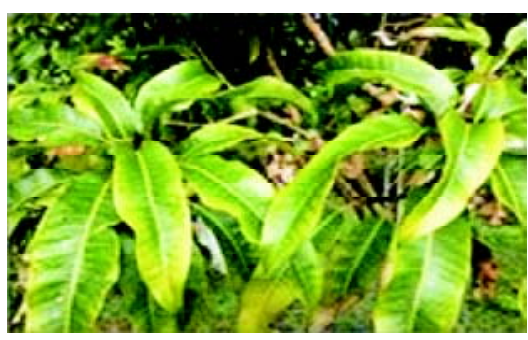

A

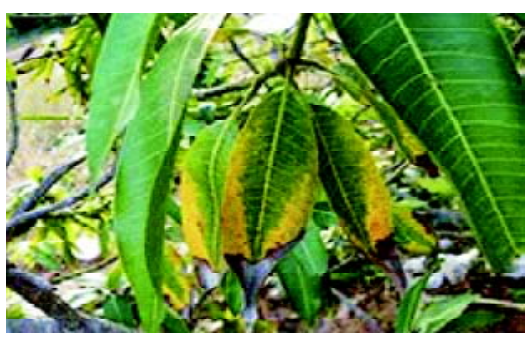

B

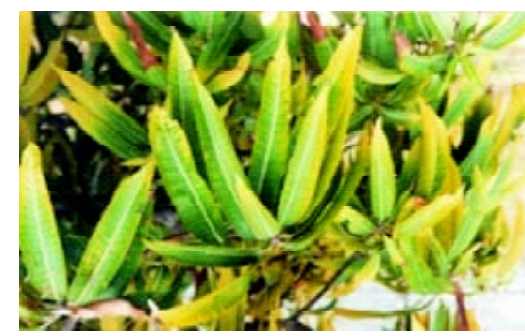

$\mathrm{C}$

Fig. 10. (A,B,C) Showing magnesium deficiency in mango (A) initial fading of green colour of recently matured leaves, (B) showing chlorosis beginning from leaf tip descending down along the margins and (C) severe yellowish brown leaf discoloration beginning from leaf tip and showing symptoms of defoliation. 


\section{Sulphur}

Sulphur deficiency symptoms in mango is seldomly observed since the application of mineral and organic fertilizers to the soil is usually sufficient to guarantee the needed levels of sulphur to the plants. Sometimes, even pesticides provide mango with the needed S levels. Sulphur is relatively a low mobility element in plant tissues. Hence the deficiency symptoms of this element are first seen in young leaves. In other species, the sulphur deficiency symptoms are similar to those of nitrogen, although they show a better distribution between young and old leaves. Generally sulphur deficiency occurs during new flush period. As a result it is a practical difficulty to notice sulphur deficiency in mango at this stage because the leaf colour slowly change from copper pink to green via yellow. The symptoms are seen first in the young tissues since sulphur is not redistributed to young leaves. Deficient plants show general loss of green colour of the foliage with symptoms first appearing on young leaves (Fig. 11), leaf tip remains green and with severe deficiency the whole leaf turns yellow. Tree growth is generally stunted, fruits develop unattractive colour and become tasteless (Ganeshamurthy et al. 2016a).

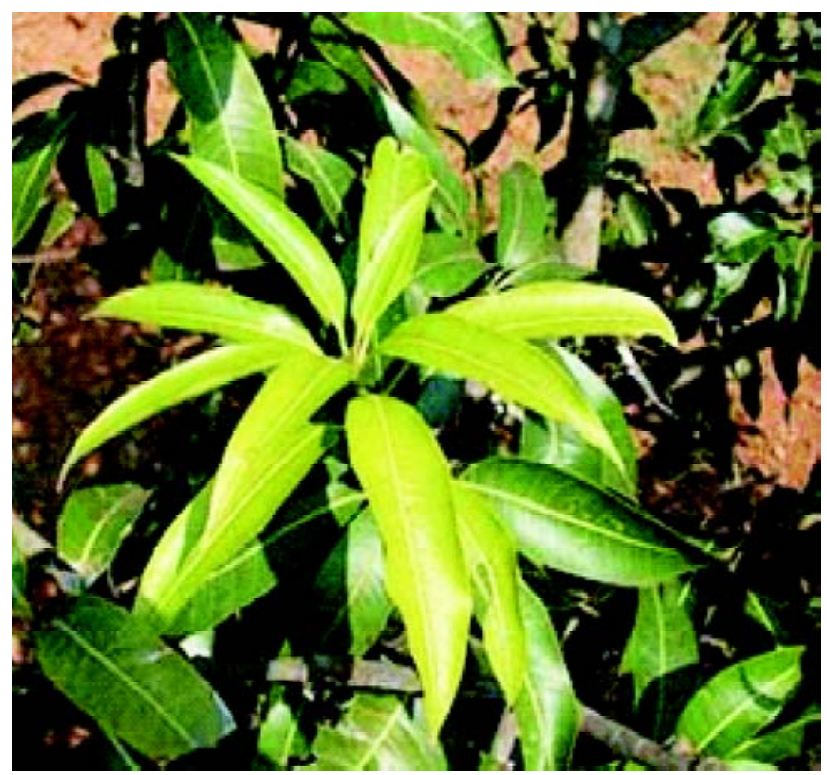

Fig 11. Showing sulphur deficiency in mango. Symptoms first appear on young leaves with

fading of green colour. Growth is stunted. Leaf tip remains green and with severe deficiency the whole leaf turns yellow.
The soil sulphur status map is presented in Fig. 12. Out of 111 districts, no information on soil sulphur status is available for 44 districts spread evenly in different regions. Sulphurdeficiency in soils is noticed in 34 districts and an equal number (33) of districts were reported sufficient in available sulphur. In case of deficiency it is better to use a sulphur containing phosphorus or potassium fertilizers rather than applying sulphur separately. Foliar spray of sulphate of potassium can also be taken up.

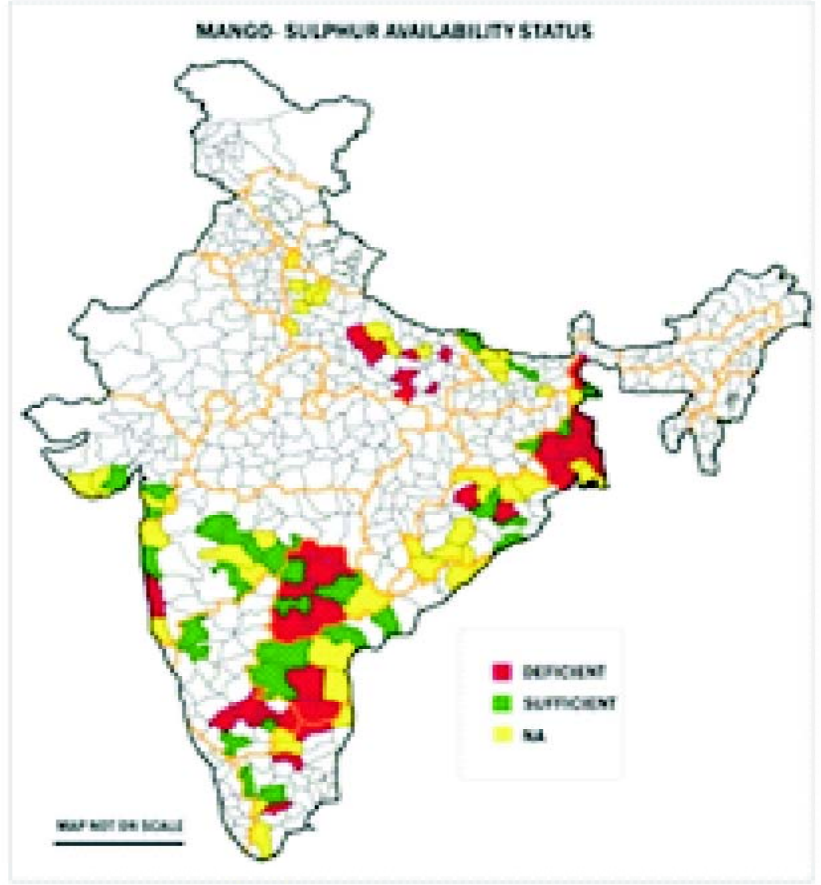

Fig. 12. Sulphur fertility status of mango growing regions of India

Zinc : Zinc is one of the most wide spread micronutrient deficiencies in mango. The main zinc deficiency symptom is exhibited in the leaves which become small, narrow, curved, thick and inflexible. Between veins a speckled brown chlorosis is sometimes seen (Fig. 13 (A, B, C). The branches produce few secondary branches and the internodes are of short length and these results in rosette appearance. Floral malformation and/or vegetative malformation or "witch broom" may, in part, be associated with zinc deficiency since the plants emit small, irregular, multiple and distorted panicles. Zinc deficiency may be more severe in fertile soils, in calcareous and limed soils or of orchards receiving high amounts of phosphorous fertilizers (Ganeshamurthy etal. 2016a). 


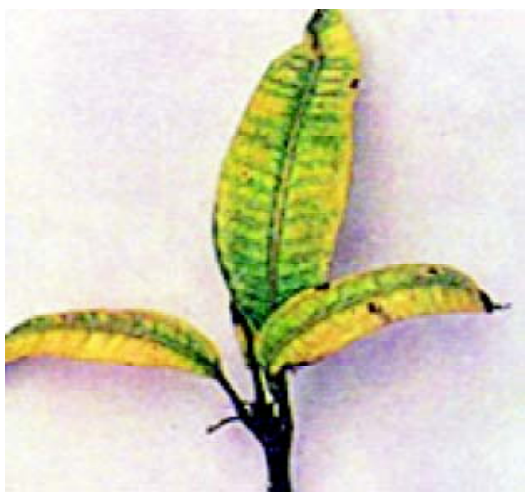

A

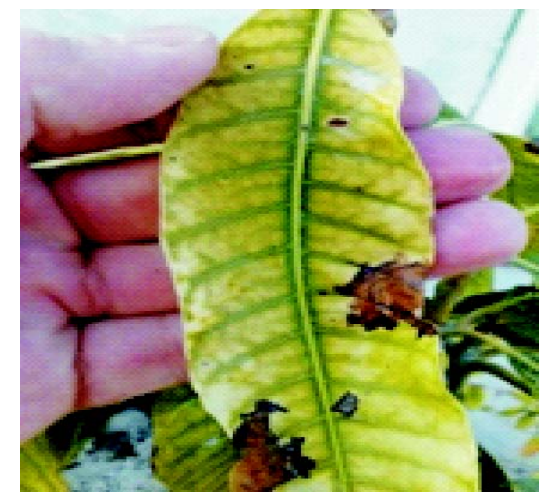

B

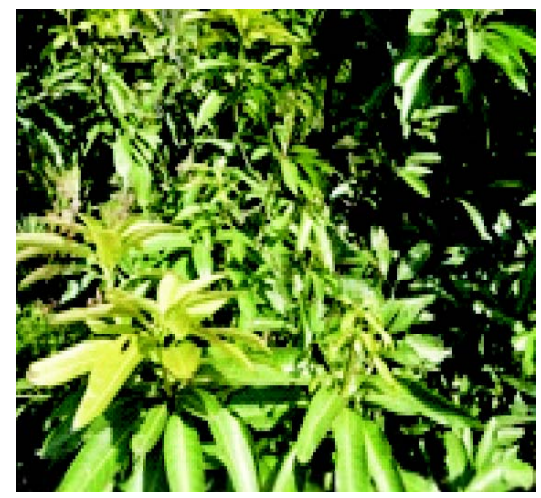

$\mathrm{C}$

Fig. 13(A,B,C). Zinc deficiency in mango(A\&B) showing interveinalchlorosis with veins remaining green and

(C) field view of a zinc deficiency showing emerging little leaves

Soil status of zinc and appearance of deficiency in mango donot match closely. Out of 111 mango districts, soils in $60 \%$ of area (67 districts) are well supplied with zinc. Only 33\% area(33 districts) shows deficient levels of soil zinc (Fig.14).

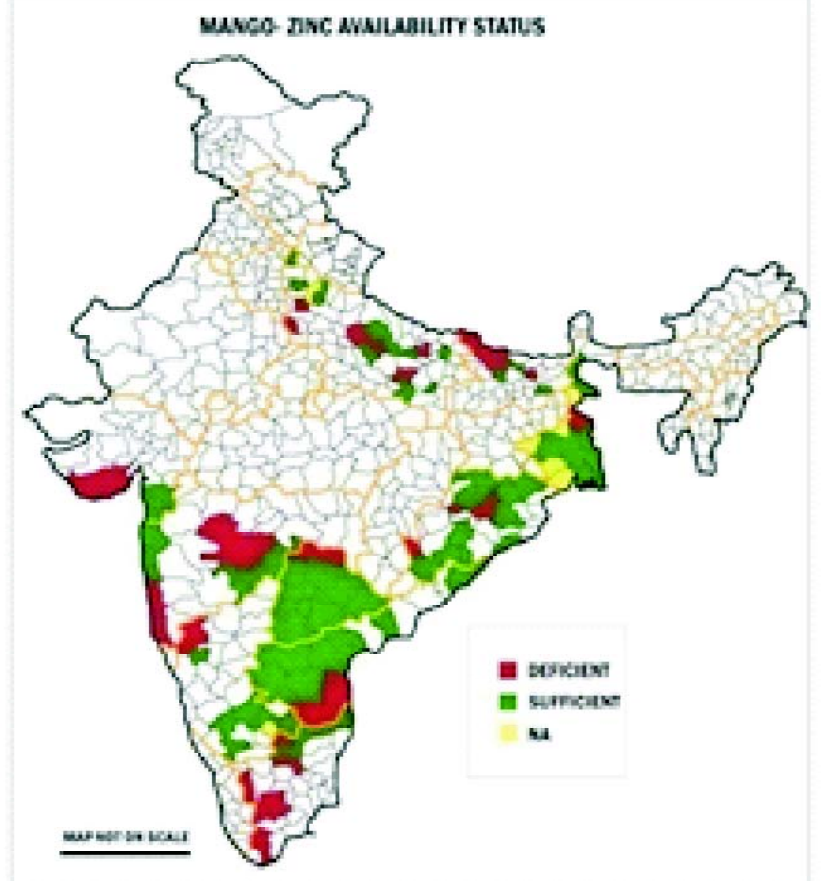

Fig. 14. Zinc fertility status of mango growing regions of India

However, no information is available for seven districts, one each in UP(J.P. Nagar) and Karnataka (Bengaluru-urban) and five in West Bengal(Malda, West Midnapore\& East Midnapore, Purulia, Birbhum). Zinc deficiency occurs during peak growth period or fruit development stage when the demand for zinc exceeds supply rate from the soil. Being immobile retranslocation from older leaves or woody part is slow. As a result the deficiency is exhibited both as hidden hunger and expressed as leaf symptoms. Foliar application of zinc corrects such deficiencies.

\section{Management of zinc}

Continuous soil application of zinc leads to its accumulation in the soil leading to nutrient imbalance in the soil. Further the uptake of foliar applied zinc in mango is more rapid than that of soil applied zinc. Hence foliar application is preferred over soil application. Zinc deficiency in mango, can be ameliorated by foliar application of zinc sulphate. Spray the plants with $0.25-0.5 \%$ zinc sulphate solution (250-500g zinc sulphate per 100 litres of water depending upon severity of deficiency) after monsoon rains just(October-November) and repeat the spray before panicle emergence. However, in some places where new flush emerges late, the spray should be done in June and if further delayed flush appears then zinc sulphate should be sprayed during August-September. Apart from this in mango, zinc deficiency becomes acute immediately after first fruit set on plants; therefore one maintenance spray of $0.3 \%$ zinc sulphate solution may be given in pre-monsoon from the third year of planting. Arka Mango special developed by IIHR may be used at $5 \mathrm{~g}$ per litre to correct zinc deficiency in addition to other micronutrient deficiencies. Those growers who wish to apply $\mathrm{Zn}$ to soil may apply one $\mathrm{kg}$ zinc sulphate per tree once in two to three years. 


\section{Manganese}

Manganese deficiency in mango is uncommon. But if exists then manganese deficiency may be the cause of reduced growth in mango plants. The first symptoms are seen in young leaves. A yellowish green colour develops in the leaf background with the veins keeping their green colour (Fig. 15). In manganese

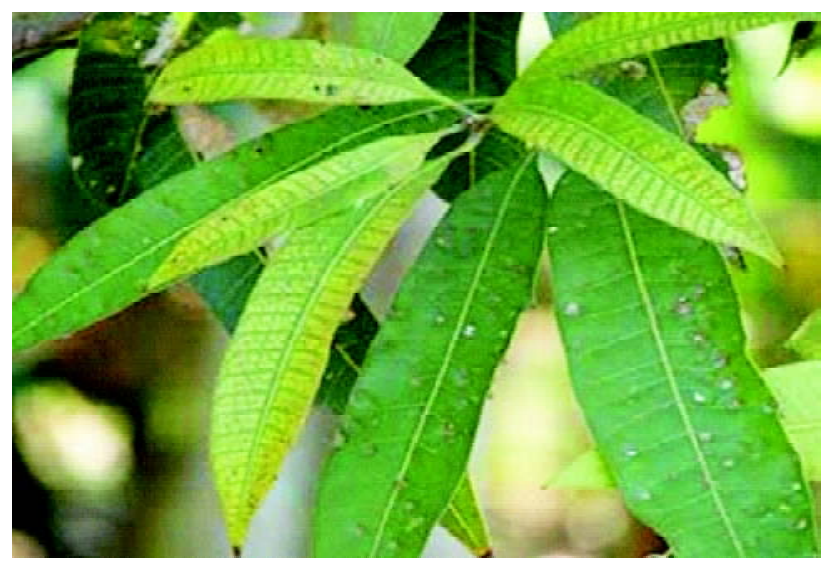

Fig. 15. Mango tree showing manganese deficiency. The tree show a yellowish green background with a fine network of green veins on the upper surface and disappearing after a few weeks mature and leaves become thicker and blunted. Specks of light grey to grayish brown colour appear under mid deficiency.

deficient leaves, the green veins are little wider than those of the iron deficient leaves. Under severe manganese deficiency, there develops a generalized yellowing of the young leaves followed by a necrosis of the leaf blade tip. Manganese deficiency in mango may be expected in soils which have received lime and high doses of $\mathrm{P}$ fertilizers as Mnavailability in the soil is reduced under such situations (Ganeshamurthy et al. 2016a).

Soil status of available manganese is presented in Fig 16. Soils in only three districts viz., Saharanpur in UP, Vaishali in Bihar, Dindigul in Tamil Nadu showed manganese deficiency. The remaining 108 districts showed adequate supply of soil manganese.

\section{Management of manganese}

Manganese deficiency is not common in mangos. However, hidden hunger might be there in sandy and light textured neutral to alkaline soils. Many fungicides and insecticides used in mango contain traces of manganese. This partially meets the manganese requirement of the trees. In case of

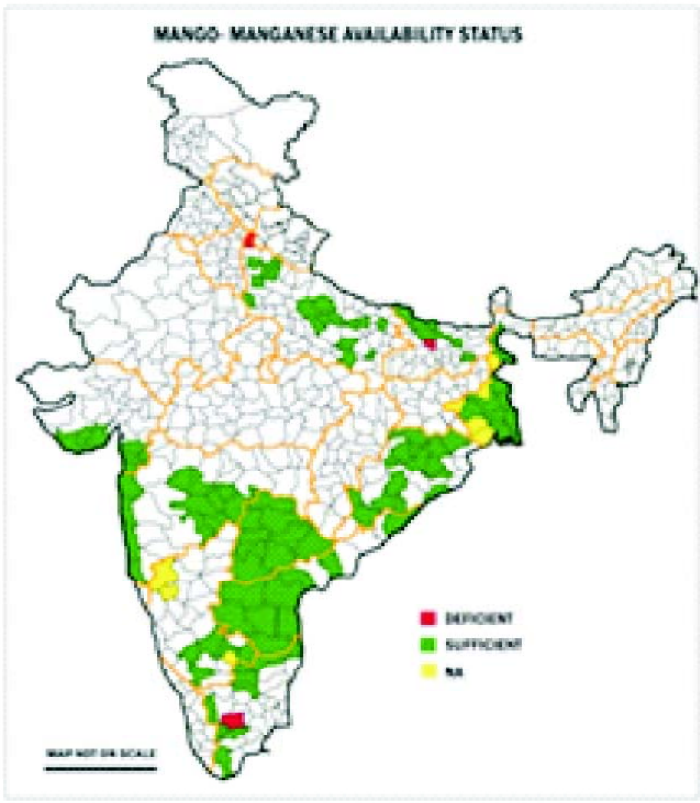

Fig. 16. Manganese fertility status of mango growing regions of India

deficiency foliar application of $0.2 \%$ manganese sulphate may be adopted rather than soil application. Arka Mango special developed by IIHR may be used at $5 \mathrm{~g}$ per litre to correct $\mathrm{Mn}$ deficiency in addition to other micronutrient deficiencies.

\section{Copper}

Copper is seldom deficient in mango plants not only because mango demand for copper is low but also because several of the fungicides used in diseases control have copper in their formula. Usually copper deficiency symptoms are seen in young plants, or in buds of adult plants, which were submitted to high doses of nitrogenous fertilizers. In copper deficient plants the development of S-shaped long and tender branches and downward curved leaves have been observed (Fig. 17). In branches, the eruption of blisters which sometimes exudates a gummy substance is one of the symptoms of copper deficiency. The terminal branches mainly those S-shaped that developed in the preceding year may undergo progressive death (Ganeshamurthy et al. 2016a).

Similar to manganese, soil available copper is sufficient in 90 districts out of 111 districts. Soils in only five districts were reported deficient in available copper. However, no information is available for 16 districts, mostly spread in Karnataka, Tamil Nadu and West Bengal (Fig. 18). 


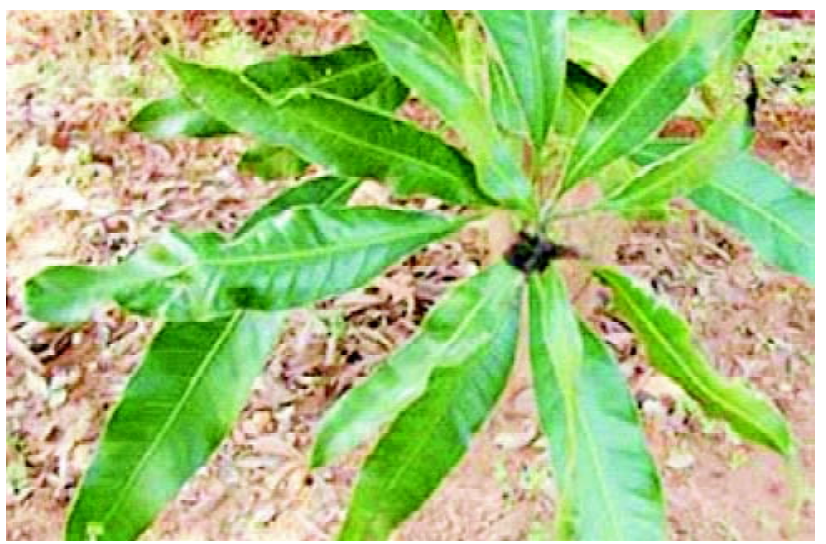

Fig. 17. Mango plant showing copper deficiency.Shoots produced on long drooping $\mathrm{S}$-shaped branches of previous growth are weak, lose foliage and die back.

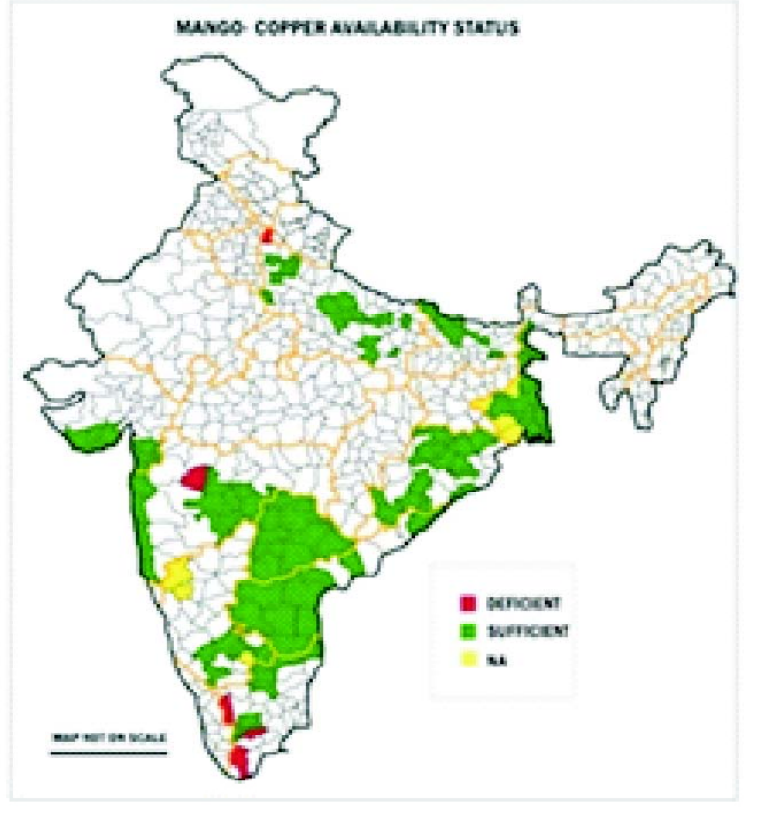

Fig. 18. Copper fertility status of mango growing regions of India

\section{Management of copper}

Copper deficiency is not common in mangos. However, hidden hunger might be there in high organic matter soils and sandy and light textured neutral to alkaline soils. As already stated many fungicides and insecticides used in mango contain traces of copper. This partially meets the copper requirement of the trees. In case of deficiency foliar application of $0.2 \%$ copper sulphate may be adopted rather than soil application. Arka Mango special developed by IIHR may be used at $5 \mathrm{~g}$ per litre to correct $\mathrm{Cu}$ deficiency in addition to other micronutrient deficiencies.
Iron

Iron deficiency in mango appears under several situations across the country. Iron deficiency occurs on trees grown on calcareous soils and those orchards receiving high bicarbonate water. Iron deficiency is very unlikely in southern peninsular region, Konkan region, North Eastern region with the exception of some soils with free calcium carbonates or bicarbonate rich waters in Chitturdistrict of Telangana and Nuzividu area of Andhra Pradesh. Sometimes in poorly drained soils excessive doses of manganese may cause iron to become unavailable to plants. If orchards receive very high doses of $P$ fertilizers, then iron deficiency may appear. Iron deficiency is initially perceived in young leaves where a typical chlorosis develops forming a green reticulate following the framework of the leaf nervures(veins) which is highlighted by the yellowish leaf blade. Severely affected leaves are of a light yellow showing none to very few green veins. Branch drying may occur under very severe deficiency conditions (Fig. 19).

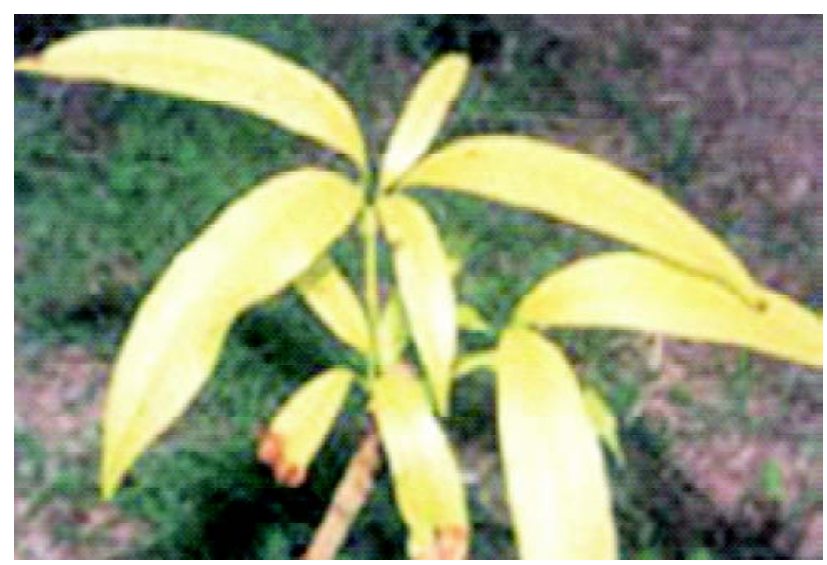

Fig. 19. Mango plant showing iron deficiency. Deficiency starts with the youngest and emerging leaves as dark yellow or white leaves. Continued deficiency causes necrosis of leaves.

Soil status of iron and appearance of deficiency in mango donot match closely. Out of 111 mango districts, soils in $82 \%$ of area (91 districts) are well supplied with iron. Only $8 \%$ area(9 districts) shows deficient levels of soil iron. However, no information is available for eleven districts (Fig.20), in UP (J.P. Nagar, Mathura), Karnataka (Belgaum, Dharwad, Bengaluru (urban)), Telangana (Nizamabad), Gujarat (Surath) and West Bengal (West Midnapore \& East Midnapore, Birbhum, Purulia,). Iron deficiency occurs during peak growth period, during first rains or fruit 


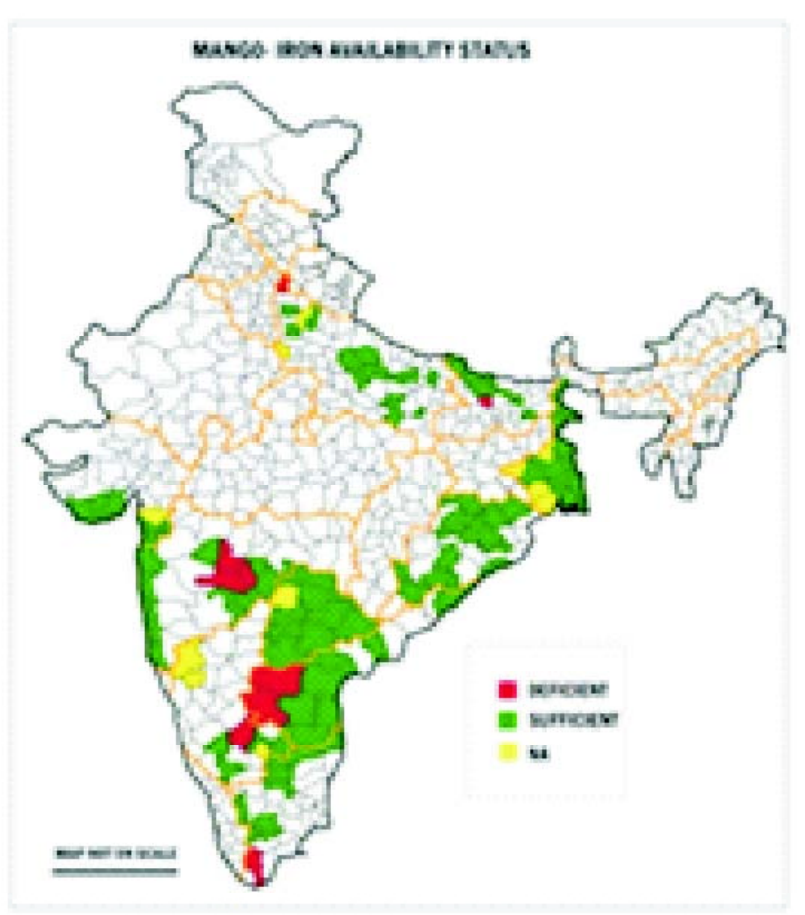

Fig. 20. Iron fertility status of mango growing regions of India

development stage when the demand for iron exceeds supply rate from the soil. Being immobile in tissue, retranslocation from older leaves or woody part is slow. As a result the deficiency is exhibited both as hidden hunger and as expressed leaf symptoms. High soil bicarbonate, calcium carbonate and irrigating with bicarbonate rich water causes iron deficiency eventhough the soil status may be high in such cases (Ganeshamurthyetal.2016a).

\section{Management of iron}

Iron chlorosis in mango is a production constraint for trees grown on calcareous soils. Application of iron to such soils may not be fruitful unless a chelated form of iron is applied. Foliar application of iron will be necessary to grow a healthy tree on these soil types.

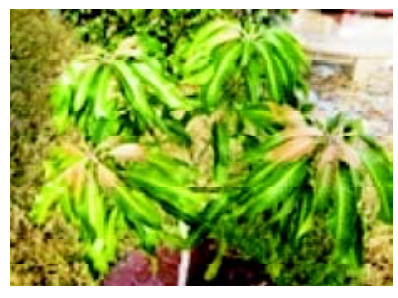

A

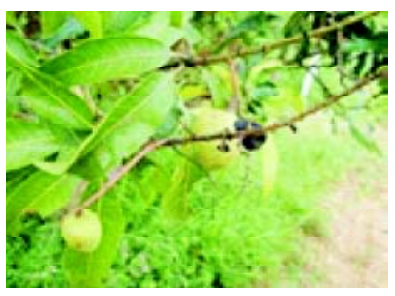

B

Iron fertilizer formulations are available that can correct chlorosis; however, the required application rate and frequency make the treatment expensive. Inorganic sources of $\mathrm{Fe}$ such as ferrous sulfate $\left(\mathrm{FeSO}_{4}\right)$ are not effective unless applied at extremely high rates; these sources should not be used on calcareous soils. The most popular synthetic organically chelated forms of Fe include Fe-EDTA, Fe-HEDTA, Fe-DTPA, and Fe-EDDHA. The effectiveness of these fertilizers varies greatly, depending on soil $\mathrm{pH}$. Fe-DTPA may be used on mildly alkaline soils (with $\mathrm{pH}$ values of 7.5 or less), whereas Fe-EDDHA is the chelate of choice for use on highly calcareous soils (with a pH value greater than 7.5). The mango special developed by IIHR, Bengaluru is a proven product that corrects both hidden and expressed iron deficiency in mango. This can be used as a foliar spray @5 grams per litre during flowering season.

\section{Boron}

Mango is one crop which is very susceptible to boron deficiency. Its manifestation varies greatly from cultivar to cultivar. Boron deficiency symptoms occur first in the young parts of the plant while toxicity is seen at the extremities of the older leaves. Boron deficiency causes leaf growth reduction and the intermediate leaves of the vegetative flux show a suede brown colour. The apical bud usually dies and with dying shoot tips, excessive lateral budding is common, resulting in a cluster of secondary branches, (Fig. 21 A,B,C,D). The panicles show a reduced size and bear a smaller number of hermaphrodite flowers and this leads to a lower number of fruits. Retention of fruit is drastically reduced, retained fruits become misshaped and gives an ugly look. Fruits of some of the varieties of mangos with boron deficiency occur in a small number and these fruits may develop brown colour. In severe cases fruits with collapsed tissues are frequently found and these symptoms have been

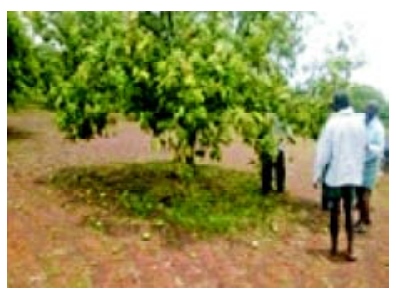

C

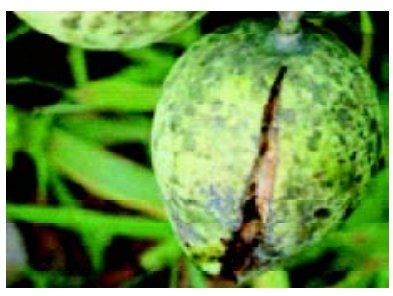

$\mathrm{D}$

Fig. 21 (A,B,C,D). Boron deficiency in mango(A) showing dying shoot tips, (B) Poor fruit set and retention, (C) field view of fruit dorp and (D) fruit cracking 
designated as "internal fruit necrosis". These symptoms start with a dark green colour located at the fruit apex which evolves with time to give the whole fruit a dark brown colour. The internal tissues of the fruit show signs of disintegration and become of a dark brown colour what, sometimes, is followed by the oozing of a gummy exudation. The adequate dose of boron is important since the difference between deficiency and excess is very small. Boron toxicity causes leaves to become with blighted margins and fall rather easily, this being possible to occur between vegetative fluxes following the application of excessive doses of boron fertilizers. Toxicity symptoms may be attenuated by applying soluble forms of other nutrients to soil, increasing soil $\mathrm{pH}$ by the application of lime or nitrogenous fertilizers although these measures may affect productivity (Ganeshamurthy et al. 2016a).

Soil availability status of boron indicated that out of 111 mango districts, no information is available for $58 \%$ of the area (64 districts). Data from 19 districts showed deficient levels of hot water soluble boron. However, only 28 district soils showed sufficiency in boron supply (Figure 22). Deficiency of boron can be easily corrected through foliar feeding. Many a times an imbalance in potassium and calcium supply

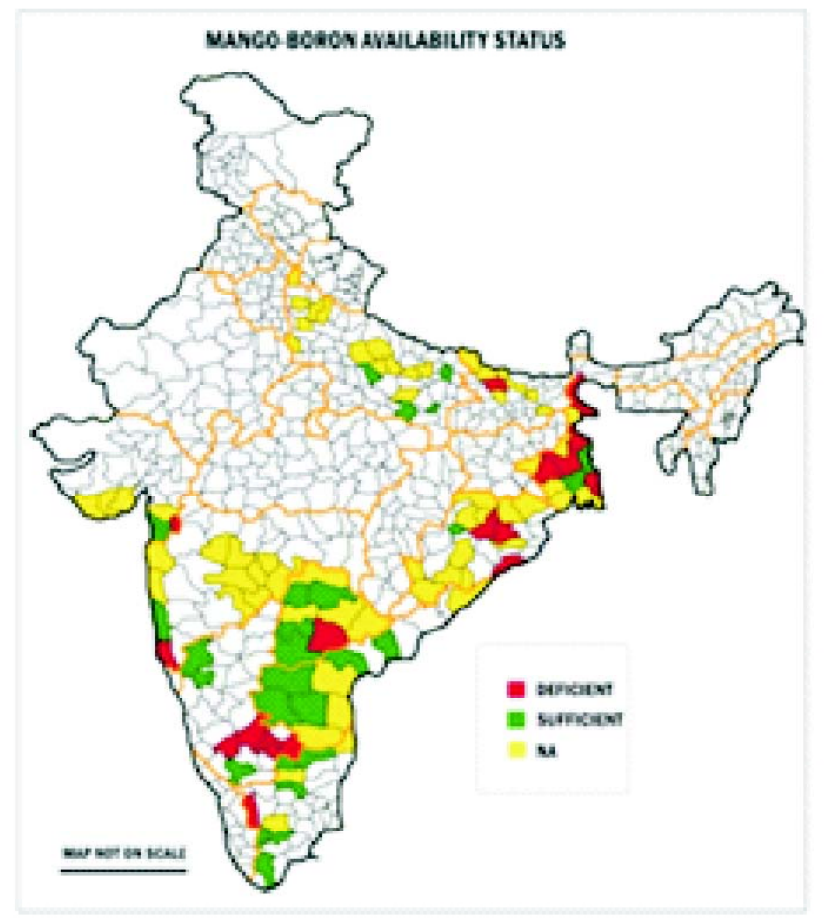

Fig. 22. Boron fertility status of mango growing regions of India relative to boron supply may also cause boron deficiency even under adequate boron supply. Hence before undertaking remedies, leaf analysis is essential.

\section{Management of boron}

Though appearance of boron deficiency in mango is very common, farmers seldom take corrective measures. If properly applied correction of boron deficiency is very easy. Applying B to the soil can provide unsatisfactory results during dry seasons and may result in toxicity problems. Basal application of boron through broadcast on surface soil is better than top dressing in boron deficient soils. Caution should be exercised in its soil application as continuous soil application leads to its accumulation and reaches toxic levels in short periods. It is better to supply boron to mango trees through foliage as foliar sprays of 0.2 per cent borax or boric acid solution were found efficient in mango.Because of its greater solubility, boric acid might be preferred over borax for foliar spray application. The spray may be applied either on recently matured flush orduring flowering. The applicator should be careful not to apply more than the recommended amount because any excess amount would result in $\mathrm{B}$ toxicity. The mango special developed by IIHR, Bengaluru is a proven product that corrects both hidden and expressed boron deficiency in mango. This can be used as a foliar spray @ 5 grams per litre during flowering season.

\section{Molybdenum}

Molybdenum as an essential element and is necessary for the activator of enzymes in respiration. It also has a role in the protein synthesis. Mo is also essential for auxin synthesis and can act as electron carriers in enzyme systems bringing about oxidationreduction reactions.

Generally Mo is not a limiting factor in mango production. No reported Mo deficiency is reported from anywhere in the country. However, fully matured leaf should contain Mo in the range of 0.05 to $0.10 \mathrm{ppm}$.Unless leaf analysis shows deficiency it is advisable to avoid application or spray of Mo in mango(Ganeshamurthyetal.2016a).

Nutrient Toxicity Symptoms : Black tip is a disorder caused mainly due to exposure of the trees to high concentrations of sulphur dioxide, carbon monoxide, ethylene and fluorides. This disorder has generally 
been detected in orchards located in the vicinity of brick kilns. Hence it is mainly accounted for the exposure of the trees to $\mathrm{SO}_{2}$ and $\mathrm{CO}$. But excess fluoride and excess ethylene has also been found to induce similar symptoms. Generally these symptoms are seen trees growing near the brick kilns which normally emit these gases (Fig. 23). Apart from these

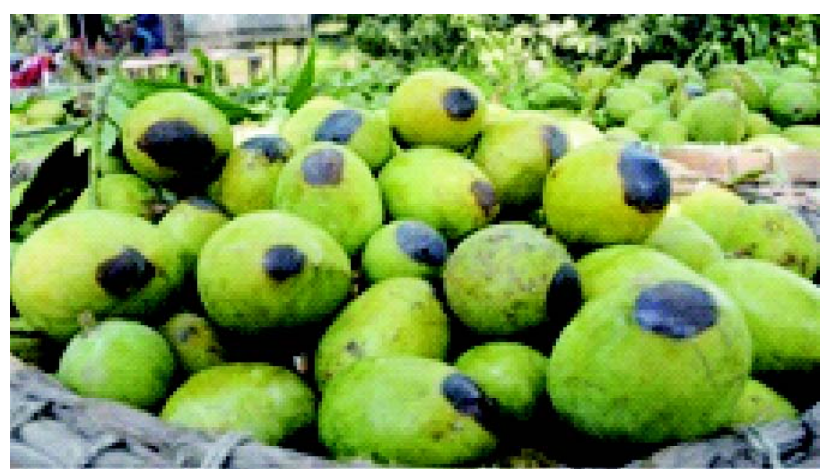

Figure 23. Black tip on mango fruits showing flattened and sunken black necrosis at the distal end of the fruits

factors, irrigation, condition of the tree and management practices also play important role in deciding the severity of the disorder. Symptoms are seen mainly on the fruits starting from marble stage. Symptoms appear as flattened and sunken black necrosis at the distal end. As the problem continues the oozing of a brown liquid starts and finally the entire fruit gets affected and drops.

Management of black tip: Farmers must avoid brick kilns near mango orchards maintaining at least 5$6 \mathrm{~km}$. from the brick kilns. If brick kilns are already there then planting must be avoided near the kilns. Affected trees must be sprayed with alkaline solutions to neutralize the effects. Two to three sprays of one per cent borax at 10 to 15 days interval beginning with marble size fruits helps minimizing the effect. If boron concentration in tree is already normal or high then it is advisable to spray two to three times $0.6-0.8 \%$ caustic soda or caustic potash or even $0.3-0.5 \%$ washing soda after complete fruit set (Ganeshamurthy etal. 2016a).

\section{Chloride and sodium injury}

Trees growing near sea shore or irrigated with high chloride water show symptoms of chloride toxicity. The leaves of such trees show marginal necrosis starting from tip extending along the margins. Excess boron application also shows similar symptoms (Fig. 24). A leaf analysis will distinguish the reasons for the leaf necrosis. In severe cases the branches of

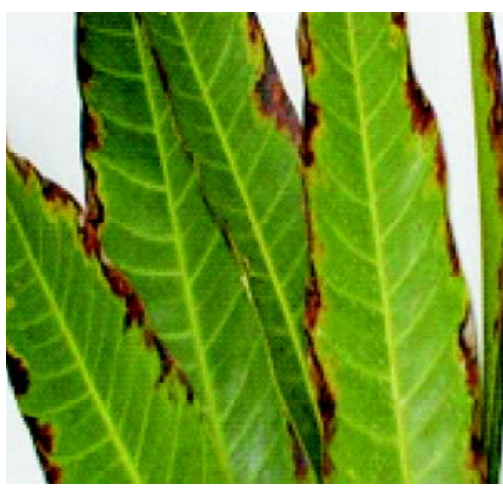

A

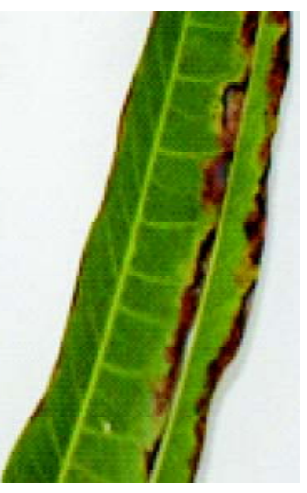

Fig. 24. Showing (A) chloride injury of leaves as necrosis of the leaf margins and (B) sodium injury showing dieback symptoms. the trees show die back symptomsIn such cases avoid irrigation with chloride rich water and donot apply any boron fertilizers either as soil application or foliar spray (Ganeshamurthy etal. 2016a).

\section{Integrated Nutrient Management}

The continuous use or excess supply of inorganic fertilizers as source of nutrient in imbalanced proportion is a problem, causing economic inefficiency, damage to the environment and in certain situations, harm the trees themselves and also to human being who consume fruits from these trees. INM involves maintainance or adjustment of tree nutrient supply to an optimum level for sustaining the desired fruit productivity. It involves proper combination of chemical fertilizers, organic manures, crop residues, $\mathrm{N}$ fixing crops, and biofertilizers suitable to the system of land use and 
ecological, social and economic situations. It has a definite edge over conventional inorganic fertilizers alone. The main goals of INM are to maintain soil productivity, ensuring sustainable mango production. It utilizes the potential benefits of green manures, crop residue recycling and biofertilizers and preventsany degradation of environment. It satisfies the social and economic aspirations of the mango farmers without harming the natural resource base. INM enhances the availability of nutrients and the release rate is matched with the crop demand for nutrients. It encourages the synergistic interaction of soil microbs and other soil fauna and minimizes the loss of nutrients by striking a balance between immobilization and mineralization.

Under INM, integrated use of organic and inorganic inputs can partly reduce the dependence on costly chemical fertilizers while improving soil quality and fruit yields. Literature available are unanimous with regard to tangible improvements in fruit yield and, in certain cases, fruit quality with the conjunctive applications of fertilizers and organic inputs (Gautametal.2012; Hasan et al., 2013; Singh etal., 2015; Yadav et al., 2009). NPK fertilizers and FYM are the common components of INM plans in mango; main difference lies in the selection of microbial inoculants(s) suggesting that a single product may not be effective under varying situations. The microbial consortium developed by IIHR has been found to have wide adoptability in expressing benefits across the agro ecological regions of mango cultivation. After a particular INM recommendation has been found effective, local farmers must be sensitized for its large-scale adoption. Subsequently, impact evaluation studies should be conducted to understand the changes, inter alia, in yields, income and soil fertility so that desirable modifications/improvements can be made for maximizing the benefits. INM inputs contains different secondary ( $\mathrm{Mg}$ and $\mathrm{S}$ ) and micronutrients ( $\mathrm{Zn}, \mathrm{B}, \mathrm{Fe}, \mathrm{Cu}, \mathrm{Mo}$ ) that are effective in enhancing mango fruit yield and quality in $\mathrm{Zn}$ and $\mathrm{B}$ deficient alfisols of peninsular India. IIHR has come out with a mango specific micronutrient formulation called "Arka Mango Special". Three foliar sprays at flower bud differentiation, flower initiation and marble stage of fruit growth significantly improve fruit retention, yield and fruit quality (TSS, TSS/acid ratio) in acidic soils of Odisha. This is recommended for all mango varieties and has shown positive effect in enhancing fruit quality in terms of fruit appearance fruit keeping quality and taste.

\section{Organic Mango Cultivation}

Mango is a candidate crop for organic production as the demand for nutrients by mango is very limited. Organic farming is a production method which encourages sustainable mango production through natural biological cycles. It is targeted at producing healthy, nutritive, pollution free mangos by minimizing the use resources from outside the system and generating resources and their use of on farm resources. In this system it avoids the use of chemical fertilizers and pesticides. Information on extent of organic mango production is not available. However few stray examples of organic mango production by individual farmers and NGOs are reported from Karnataka, Andhra Pradesh Maharashtra and Tamil Nadu. In the last few years, H" 300-400 tonnes of mangoes are being organically produced in Krishnagiri district of Tamil Nadu. For the existing mango orchards, a minimum of three years is required as conversion period for organic cultivation. To start organic mango production one has to either start afresh or convert an existing orchard into an organic orchard. This requires procedures to be followed for organic certification. Conversion from a conventional system to an organic system involves changes to existing management practices and adoption of a new strategy and techniques. Some of the major changes required are in pest and disease control strategies, nutrient management, weed control, flowering, and postharvest management. All these can be achieved through transformation from a conventional system to an organic system of growing mangoes. While converting the existing orchard to organic system farmers must develop strategies tailored to their situation through close observation, anticipation and prevention to develop a robust and productive organic system. While doing so care should be taken to consider and integrate the following three points:

- Organic systems are biological systems.

- Organic farms should operate as closed systems as far as possible.

- Soil health largely determines plant health. 
As with other organic farming, mango production requires a whole-farm approach. Many of the best management practices developed for conventional mango production apply to organic systems. Efficient irrigation, windbreaks, erosion control, and aspects of integrated pest management (IPM) or integrated weed management (IWM) may be adapted to suit an organic production system. Periodic analysis of both soil and fruits for hazard analysis and critical control points must be undertaken. A well designed whole-farm plan should devote special attention to the conversion phase - the first three years of transition from conventional to organic management. Availability of bio-control methods for pest-diseases management and chemical-free postharvest treatments further increase the scope of organic mango farming; especially in marginal areas where little or no agrochemicals are applied.

\section{Mango orchards for carbon sequestration}

Carbon sequestration is the process by which carbon dioxide $\left(\mathrm{CO}_{2}\right)$ from the atmosphere is absorbed by trees through photosynthesis and stored as carbon in tree biomass such as tree trunks, branches, foliage, roots and soils (EPA, 2010). The amount of carbon sequestered by trees and soils is a tool for determining the sustainability and environmental impact of carbon on ecosystems. Carbon sequestration rates vary by tree species, soil type, regional climate, topography and management practice. Fruit crop orchards are seen as the alternative way to help solve effects resulting from the depletion of the forest through the degradation and deforestation of forest in order to replace the lost forest and increase the reservoir base for carbon sequestration. Mango being the most important fruit crop of India and occupying the largest area under fruit crops, the ability of mango plantation to sequester carbon needs special attention. A national data base of carbon sequestered by mango orchards forms the basis for claiming carbon credits. Estimation of CS potential of fruit orchards was hindered by lack of methodologies for non-distructive estimation of tree biomass until Ganeshamurthy et al. (2016c) developed the allometric equation for the grafted mangos. They have also estimated the carbon stocks of Konkan mango orchards(8.7 million tonnes) covering the Konkan area of Karnataka, Goa and
Maharashtra. Some of the research findings on carbon sequestration in mango based agroforestry systems in India is summarized in Table 9. However, the data is based on general allometric equations meant for polyembrionic trees and hence this must be looked at with caution.

\section{Way Forward}

Recent efforts in doubling of agricultural production have been successful through intensification leading to increased yields per unit area. The potential for a further doubling in yields now attracts increasing attention and research. There is need to revitalize yield growth in a sustainable manner by reducing the inputs and using fewer resources. The current trend is to focus on ecological intensification, sustainable intensification and evergreen revolution. Constraints are bound to occur in the way including land and water, environmental degradation and climate change. A two way schematic representation of how we must approach the issue of enhancing the productivity and yield of mango without degrading the environment is presented in fig. 25. We must adopt suboptimal tree and soil management practices to enhance the productivity and income of the farmers. The challenge is how to apply good governance using existing agricultural sciences and technologies without affecting the needed advances in tree productivity and yield.

We must aim at a new trajectory for achieving our goal of doubling the farmers income through enhancing the productivity and yield of mango. In this direction we must focus on two main components. (i) the development of integrated soilorchard systems management, which will address key constraints in existing tree management, and (ii) look for new ways that offer higher yields but use less water, fertilizer or other inputs and insulate against drought, heat, submersion, and pests and diseases. Conservation horticulture holds the key. Efforts must be made to create awareness among mango farmers and popularize the concept of conservation horticulture to achieve the goal of enhanced mango productivity and yields.

\section{Application and extension of existing technologies countrywide}

Mango is national fruit and deserves a nationwide attention to achieve the top position in the world to retain the title of national fruit and to help the farmers 
Enhancing mango productivity through sustainable resource management

Table 9. Examples of carbon sequestration in mango orchards across India.

\begin{tabular}{|c|c|c|}
\hline Region & Finding & Reference \\
\hline $\begin{array}{l}\text { Poanta valley, } \\
\text { Himachal Pradesh }\end{array}$ & $\begin{array}{l}\text { Total SOC pool was highest in forest land }\left(1373.7 \mathrm{t} \mathrm{ha}^{-1}\right) \\
\text { followed by horti-silvipastoral (mango + poplar + } \\
\left.\text { grasses; } 719.6 \mathrm{t} \mathrm{ha}^{-1}\right) \text { and least in silvi-pastoral system } \\
\left(\text { Dalbergiasissoo + grasses; } 599.10 \mathrm{t} \mathrm{ha}^{-1}\right)\end{array}$ & $\begin{array}{l}\text { Khaki } \\
\text { et al. (2016) }\end{array}$ \\
\hline Mollisols, Uttarakhand & $\begin{array}{l}\text { Organically managed pulse crops (LTFE), mango and } \\
\text { Dalbergia systems were found to be the most sustainable } \\
\text { land use systems. Mango orchard soils had the highest } \\
\text { total carbon }\left(23.25 \mathrm{~g} \mathrm{~kg}^{\prime \prime}\right) \text { and total organic carbon } \\
\left(23.21 \mathrm{~g} \mathrm{~kg}^{\prime \prime}\right)\end{array}$ & $\begin{array}{l}\text { Bhattacharjya } \\
\text { et al. (2017) }\end{array}$ \\
\hline $\begin{array}{l}\text { Central Himalayan } \\
\text { Tarai region }\end{array}$ & $\begin{array}{l}\text { Total C-sequestration in mango }\left(15 \mathrm{y} ; 100 \text { trees }^{-1}\right) \\
\text { was } 21.4 \mathrm{tha}^{-1} \text { compared to only } \mathrm{H}^{-1} 6.5 \mathrm{tha}^{-1} \text { in } \\
\text { both litchi }\left(7 \mathrm{y} ; 100 \text { trees ha- }{ }^{-1}\right) \text { and plum }(5 \mathrm{y} ; 400 \text { trees } \\
\left.\text { ha }^{-1}\right) \text { which seemed to be due to their low } \\
\text { C-sequestration rates }\left(0.94 \text { and } 1.28 \mathrm{tha}^{-1} \mathrm{y}^{-1} \text {, }\right. \\
\text { respectively) than } 1.43 \mathrm{tha}^{-1} \mathrm{y}^{-1} \text { in mango. }\end{array}$ & $\begin{array}{l}\text { Kanime } \\
\text { et al.(2013) }\end{array}$ \\
\hline Tamil Nadu & $\begin{array}{l}\text { Highest TOC was recorded in teak soils }(0.69-1.11 \%) \\
\text { followed by mango }(0.64-0.85 \%) \text {, sapota }(0.36-1.07 \%) \\
\text { and coconut }(0.57-0.81 \%) \text { at } 0-20 \mathrm{~cm} \text { depth in } 20 \text {-years } \\
\text { old trees. }\end{array}$ & $\begin{array}{l}\text { Selvaraj } \\
\text { et al. (2016) }\end{array}$ \\
\hline Eastern plateau region & $\begin{array}{l}\text { In } 6-y \text { old litchi, mango and guava orchards }(5 \times 5 \mathrm{~m}) \text {, } \\
\text { the maximum total SOC in } 0-60 \mathrm{~cm} \text { depth was noted in } \\
\text { mango }(62.47 \mathrm{Mg} \text { ha"1) that was } 17.2 \% \text { higher over } \\
\text { control. The higher total SOC in mango orchards } \\
\text { may be attributed to the higher amount and quality of } \\
\text { mango litter. }\end{array}$ & $\begin{array}{l}\text { Naik } \\
\text { et al.(2017) }\end{array}$ \\
\hline
\end{tabular}
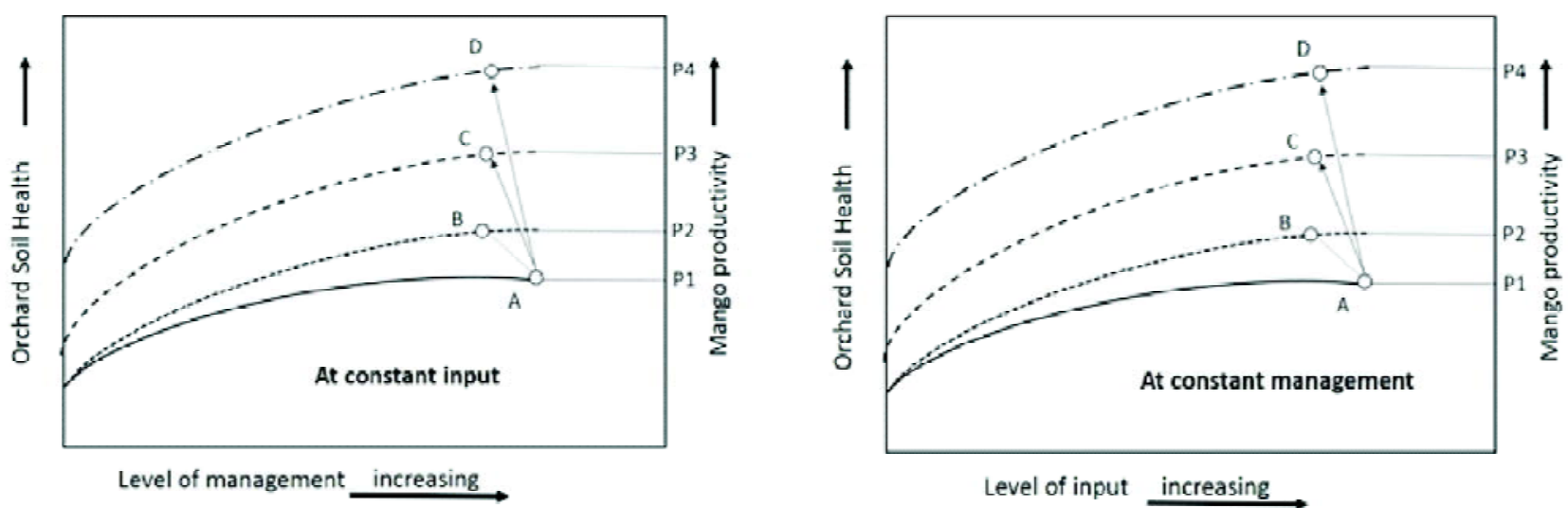

Fig 25. A two way schematic representation of approaches to enhance the productivity and yield of mango

to make profit from mango orchards. Available evidence suggests that the yield gap between average farm yields and the experiments yield on research farms are derived from factors such as: (i) low profitability of mango production; (ii) limited access to new orchard technologies, and (iii) poor soil and orchard management by farmers. We must focus on a mission mode to adopt the available technologies of orchard management across the country to enhance the productivity, yield and profitability of mango orchards and achieving the goal of doubling the income of mango farmers by 2022 . 


\section{REFERENCES}

Ali, S. M., Bai, K., Hanumantharaya, B.G and Nagraj, K.H (2017). Micro-Catchment Techniques: An Effective Water Conservation Practice in Mango. Int. J. Curr. Microbiol .App. Sci (2017) 6(5): 2965-2969

Baldock, J. O. and Schulte, E. E. 1996. Plant analysis with standardized scores combined with DRIS and Sufficiency ranges approaches in corn. Agronomy. J. 88: 448-456

Biswas B. C. and Kumar Lalit. 2012. Revolution in Mango Production Success Stories of Some Farmers. Fertiliser Marketing News March 2011. Pp 1-24.

Beaufils, E. R. 1973. Diagnosis and Recommendation Integrated System (DRIS): a general scheme for experimentation and calibration based on principle developed from research in plant nutrition, South African Soil Sci., Bulletin No.1

Bhattacharjya, S., Bhaduri, D.,Chauhan, S., Pareek, N., Chandra, R and Pareek, N. 2017. Comparative evaluation of three contrasting land use systems for soil carbon, microbial and biochemical indicators in North-Western Himalaya. Ecological Engineering 103:21-30

Bhosale S.S, Sonawane, K.G, and Shinde, V.A. 2016.Economics of Kesar Mango Production In Plain Zone Of Western Maharashtra. International Journal of Agriculture Sciences. 8, 1912-1915.

Burondkar, MM.,Gunjate, RT, Magdum, MB and Govekar, MA. 2000. Rejuvenation of old overcrowded alphonso mango orchard with pruning and use of paclobutrazol. Acta Hortic. 509, 681-686.

Burondkar M M, Rajan S, Upreti K K, Reddy Y T N, Singh V K, Sabale S N, Naik M M, Ngade P M and Saxena P. 2013. Advancing Alphonso mango harvest season in lateritic rockysoils of Konkan region through manipulation in time of paclobutrazol application. Journal of Applied Horticulture 15: 178-82

Cotrim, C.E.; Coelho Filho, M.A.; Coelho, E.F.; Ramos, M.M.; Cecon, P.R.2011. Regulated deficit irrigation and 'Tommy Atkins' mango orchard productivity under microsprinkling in Brazilian semiarid. Engenharia Agrícola, Jaboticabal, v. 31 , n. 6 , p. 1052-1053.

English, M.J.; Raja, S.N. 1996. Perspectives on deficit irrigation. Agric. Water Manag. 32, 1-14.

EPA (2010).Environmental co-benefits of sequestration practices. Internet file http;//www. epa.gov/ sequestration/fag.html April, 2012.

FAO (2017). FAO Statistical Programme of Work 2016-2017. FAO.

Ganeshamurthy, A.N and Reddy, Y.T.N. 2015. Fitness of Mango for Colonization in Low Fertility Soils and Dry Lands: Examination of Leaf Life-Span, Leaf Nutrient Resorption, and Nutrient Use Efficiency in Elite Mango Varieties. Agric. Res. 4: 254-260.

Ganeshamurthy, A.N. Satisha, G.C. Kailash Kumar and Tarun Adak. 2016a. Soil Fertility and Crop Nutrition in Mango: Delineation, Deficiencies and Management of Nutrients. Technical Bulletin : ICAR-Indian Institute of Horticultural Research, Bengaluru

Ganeshamurthy1, A. N., Ravindra1, V., Panneerselvam1, P., Sathyarahini1 K.\&Bhat R. M. 2016b. Conservation horticulture in Mango Orchards: Comparative Effects of Conventional and Conservation Management Practices on Soil Properties of an Alfisol under Seasonally Dry Tropical Savanna Climate. Journal of Agricultural Science; Vol. 8, No. 7; 2016 
Ganeshamurthy A. N. V. Ravindra R. Venugopalan Malarvizhi Mathiazhagan\& R. M. Bhat. 2016c Biomass Distribution and Development of Allometric Equations for Non-Destructive Estimation of Carbon Sequestration in Grafted Mango Trees. Journal of Agricultural Science; 8:1-11.

Ganeshamurthy, A.N., Kalaivanan, D and Satisha, G.C. 2016d. Management of Fruit Crops in Acid Soils of India. In (K.V.Petered) Innovations in Horticultural Sciences: New India Publishing Agency, New Delhi, India January 2016

Ganeshamurthy, A.N., Ravindra V. \& Bhatt. R.M. 2018. A.N. Ganeshamurthy, G.C. Satisha, Kailash Kumar and Tarun Adak - 2016. Soil Fertility and Crop Nutrition in Mango: Delineation, Deficiencies and Management of Nutrients. Technical Bulletin : ICAR-Indian Institute of Horticultural Research, Bengaluru.

Gautam, U.S., Singh, R., Tiwari, N. 2012. Effect of integrated nutrient management in mango cv. Sunderja. Indian Journal of Horticulture $69(2): 151-155$.

Hasan, M.A., Manna, M., Dutta,P., Bhattachary a, K, Mandal, S., Banerjee, H., Ray , S.K. and Jha, S., Acta Hort.992, Nutrient Management in Fruit Crops : Issues and Strategies IX International Mango Symposium(2012).

Kanime N, Kaushal R, Tewari S K, Raverkar K P, Chaturvedi S and Chaturvedi O P (2013) Biomass production and carbon sequestration in different tree-based systems of Central Himalayan Tarai region. Forests, Trees and Livelihoods 22: 38-50

Khaki,B.L., Wani,A.A., Bhardwaj D.R. and V.R.R. Singh. 2016. Soil carbon sequestration under different agroforestry land use systems Indian Forester, 142: 734-738.
Krishna, B. Kale, A.N. Dhake and A.V. Deshpande, S.S and Balsubrahmanyam V.R. 2009. High density plantation in marginal soils and processing of mango. Acta Horticulturae 820: VIII International Mango Symposium

Kumar,D, Pandey, V and Vishal Nath. 2008. Effect of organic mulching and irrigation schedule through drip on growth and yield of 'LatSundari' mango (Mangiferaindica) in eastern region of India. Indian Journal of Agricultural Sciences 78:385-388.

Kumar, S., Ramilanb, T., Ramaraoc, C.A. SrinivasaRao Ch., Whitbread, A. 2016. Farm level rainwater harvesting across different agro climatic regions of India: Assessing performance and its determinants. Agricultural Water Management 176 (2016) 55-66

Kurian 2016High density mango tech bull. IIHR

Lal B and Mishra D. 2007. Effect of pruning on growth and bearing behaviour of mango cv. Chausa. Indian Journal of Horticulture 64: $240-2$

Lal B and Mishra D. 2008 Studies on pruning in mango for rejuvenation, Indian Journal of Horticulture 2008, 65, 405- 408

Meena, NK and Asrey,R. 2018. Tree age affects physico-chemical, functional quality and storability of Amrapalimango fruits. Journal of the Science of Food and Agriculture 98(9) 3255-3262.

Menzel, C.M and Le Lagadec, M.D. 2017. Can the productivity of mango orchards be increased by using high-density plantings? Scientia Horticulturae 218 (2017) 222-263.

Mitra, S.K. 2016. Mango production in the world present situation and future prospect. Acta Naik et al. (2017).Hortic.287-296 
Naik,S.K., Maurya,S and Bhatt, B.P. 2017. Soil organic carbon stocks and fractions in different orchards of eastern plateau and hill region of India. Agroforestry Systems 91(3):541-552

NHB 2017. Horticultural Statistics at a Glance 2017 Horticulture Statistics Division Department of Agriculture, Cooperation \& Farmers Welfare Ministry of Agriculture \& Farmers Welfare Government of India

Pawar,.H, D \&Sarwade,S.G. 2006. Evaluation of performance of intercrops in mango orchards. Journal of Soils and Crops, 16 No.2 pp.352354

Raghupathi, H. B., Reddu, Y. T. N., KurianReju, M., Bhargava, B. S. 2005. Diagnosis of Nutrient Imbalance in Mango by DRIS and PCA Approaches. J. Plant Nutrition. 27(7): 11311148.

Raj, G. B and Rao,A.P. 2006. Identification of Yield Limiting Nutrients in Mango through DRIS Indices. Communications in Soil Science and Plant Analysis, 37:11-12, 176

Rao, K. D. and Rao, D. S. K., 2007, Evaluation of different vegeTables as inter crops in rainfed mango orchards under lateritic soils of Andra Pradesh. Agri. Sci. Digest, 27 (4): 295- 296.

Rathore, A C, SarojP. L. LalH. Sharma N. K. Jayaprakash J. Chaturvedi O. P. Raizada A. Tomar J. M. S. PradeepDogra. 2013. Performance of mango based agri-horticultural models under rainfed situation of Western Himalaya, India. Agroforest Syst DOI 10.1007/ s10457-013-9646-5

Reddy, YTN andKurian, RM. 2011. Studies on rejuvenation of old, unproductive 'Alphonso' mango trees in orchards. J. Hortl. Sci. Vol. 6(2):145-147, 2011

Sahoo, U.K. 2016. Effect of Intercropping on Soil Health and Yield Potential of Mango in Paradise
Valley, East Kawlchaw, Saiha District of Mizoram, NE India. International Journal of Ecology and Environmental Science. 42(3)

Sarkar S.K., Gautam B., Seethambran Y., and Vijay N., 2004, Effect of intercropping sequence with vegetable in young mango orchard under Decan plateau, Indian J. Hort., 61(2): 125-127

Selvaraj, A., Jayachandran, S., Thirunavukkarasu, D.P., Jayaraman, A and Karuppan, P. 2016. Carbon sequestration potential, physicochemical and microbiological properties of selected trees Mangiferaindica L., Manilkarazapota L., Cocosnucifera $L$. and Tectonagrandis $L$. Bioscience Discovery, 7(2):131-139

Sharma, R.R and Singh, R. 2006 Effect of pruning intensity on light penetration and leaf physiology in Amrapali mango trees under high density planting. Tropical Science 46(1):16 - 19

Singh, Karamveer. 2008. A Study on Adoption of Improved Practices of Fruit Crops and their Constraints in Western U.P., Unpublished Ph. D. thesis, Department of Agricultural Extension, J. V. College, Baraut, Baghpat, U. P.

Singh, S.K., Singh, S.K., Sharma, R.R., 2010. Effects of pruning on the biochemical status of shoot buds in three mango (Mangifera indica L.) cultivars planted at high density. J. Hortic. Sci. Biotechnol. 85, 483-490.

Singh, P. Singh M.K. Kumar, , V, Kumar, M. and Malik S. 2012. Effect of physico-chemical treatments on ripening behavior and post-harvest quality of Amrapali mango (Mangiferaindica L.) during storage. J Environ. Biol, 33 (2012), pp. 227-232

Singh, A., Singh, V.K., Ravishankar, H., Shukla, G.K., 2014. Time series application for quantification of alternate bearing intensity (ABI) in mango (Mangiferaindica L.) cvLangra. Indian J. Agric. Sci. 84, 137-141.

Singh V.K, Anurag Singh M., Kumar Soni Singh K andAnshuman Singh. 2015. Increasing 
Profitability of Mango (Mangiferaindica L.) Orchard through Intercropping. Acta Hort. 2015; 1066:151-158.

Singh, Shyam Prakash., Adarsha, L.K., Nandi A. K. and Jopir Ome.2018. Production Performance of Fresh Mango in India: A Growth and Variability Analysis. Int. J. Pure App. Biosci. 6 (2): 935-941 (2018)

Stoll, M., Loveys, B., Dry, P., 2000. A Review on Partial Root-Zone Drying Irrigation J. of Experimental Botany, 51: 1627-1634.

Swain, S. C.D. Dora, K. Sahoo, S. C. Padhi S. K. \& Sanyal. D. 2012. Influence of Mango-Based Intercropping Systems on Improvement of Soil Health under Rainfed Situation. Communications in Soil Science and Plant Analysis 43:15, 2018-2026
Tiwari, R and Baghel B.S. 2014. Effect of intercropping on plant and soil of Dashehari mango orchard under low productive environments. Asian J. Hort., 9 (2) 439-42.

Verma, RR., Manjunath, BL \& Singh, N. P. 2013. Low Cost Rain Water Harvesting Technology (Jalkund), Technical Bulletin No. 32, ICAR Research Complex for Goa (Indian Council of Agricultural Research), Old Goa-402402, Goa, India.

Yadav, D. K.; Singh, G.; Singh, A. K. and Yadav, A. L. (2009). Effect of integrated nutrient management on plant growth and properties of aonla orchard under sodic soils condition. Plant Arch. 9 (1): 403-405.

Zuazo, D.V.H., Rodríguez, P.C.R., and Franco, T.D. 2006,. Fruit Yield, Growth and Leaf Nutrient Status of Mango Trees Grafted on Two Rootstocks in a Marginal Growing Area (SouthEast Spain). Fruits, 61, 1-7.

(MS Received 29 April 2018, Revised 13 May 2018, Accepted 27 June 2018) 